Article

\title{
Forage Availability and Quality, and Feeding Behaviour of Indigenous Goats Grazing in a Mediterranean Silvopastoral System
}

\author{
Youssef Chebli ${ }^{1,2, * \mathbb{D}}$, Samira El Otmani ${ }^{1,2}$, Jean-Luc Hornick ${ }^{2} \mathbb{D}$, Abdelhafid Keli ${ }^{3} \mathbb{D}$, Jérôme Bindelle ${ }^{4}(\mathbb{D}$, \\ Jean-François Cabaraux ${ }^{2}$ (D) and Mouad Chentouf ${ }^{1}$ (D) \\ 1 Regional Center of Agricultural Research of Tangier, National Institute of Agricultural Research, Avenue \\ Ennasr, BP 415 Rabat Principale, Rabat 10090, Morocco; samira.elotmani@inra.ma (S.E.O.); \\ mouad.chentouf@inra.ma (M.C.) \\ 2 Department of Veterinary Management of Animal Resources, FARAH, Faculty of Veterinary Medicine, \\ University of Liège, 4000 Liege, Belgium; jlhornick@uliege.be (J.-L.H.); jfcabaraux@uliege.be (J.-F.C.) \\ 3 Department of Animal Production and Pastoralism, Ecole Nationale d'Agriculture de Meknès, Meknes 50001, \\ Morocco; akeli@enameknes.ac.ma \\ 4 Precision Livestock and Nutrition Unit, TERRA Teaching and Research Center, Gembloux Agro-Bio Tech, \\ University of Liège, 5030 Gembloux, Belgium; jerome.bindelle@uliege.be \\ * Correspondence: youssef.chebli@inra.ma or ychebli@alumni.uliege.be
}

check for updates

Citation: Chebli, Y.; El Otmani, S.; Hornick, J.-L.; Keli, A.; Bindelle, J.; Cabaraux, J.-F.; Chentouf, M. Forage Availability and Quality, and Feeding Behaviour of Indigenous Goats Grazing in a Mediterranean Silvopastoral System. Ruminants 2022, 2, 74-89. https://doi.org/ 10.3390 /ruminants2010004 Academic Editor: Brian J. Leury Received: 29 November 2021 Accepted: 12 January 2022 Published: 13 January 2022

Publisher's Note: MDPI stays neutral with regard to jurisdictional claims in published maps and institutional affiliations.

Copyright: (c) 2022 by the authors. Licensee MDPI, Basel, Switzerland. This article is an open access article distributed under the terms and conditions of the Creative Commons Attribution (CC BY) license (https:// creativecommons.org/licenses/by/ $4.0 /)$.

\begin{abstract}
The aim of this study was to evaluate the feeding behaviour of indigenous goats and the selection drivers of different plant species in a Mediterranean forest rangeland. To achieve this goal, the seasonal variations in terms of forage availability and quality of ingested plant species were studied during three grazing seasons. In the same period, eight indigenous goats of Beni Arouss breed were selected to explore the seasonal changes in their browsing behaviour. Forage quality was determined by the hand-plucking technique. The results showed a wide seasonal variation in forage availability and quality, and feeding behaviour. Woody species were more selected independently of the season $(p<0.001)$. The crude protein content varied from $53.3 \mathrm{~g} / \mathrm{kg}$ of dry mater (DM) for Erica arborea in summer to $197 \mathrm{~g} / \mathrm{kg}$ DM for Calicotome villosa in autumn $(p<0.001)$. Despite the high condensed tannins content in selected shrubs, they were highly consumed. In vitro organic matter digestibility (IVOMD) and metabolizable energy (ME) had recorded the highest contents in herbaceous during spring. Shrubs and trees contain the lowest levels of IVOMD $(<500 \mathrm{~g} / \mathrm{kg})$ and ME $(<7.2 \mathrm{MJ} / \mathrm{kg})$ during autumn and summer. It is concluded that seasonal changes in forage availability and quality did not necessarily affect the indigenous goats' preference. These findings could help goat herders to develop feeding and grazing systems while increasing the performance of goats in the Mediterranean silvopastoral system.
\end{abstract}

Keywords: bite mass; browsing behaviour; chemical composition; diet composition; digestibility; forest rangeland; goat; intake rate; ruminant; selectivity

\section{Introduction}

Silvopastoral systems are an important component of extensive goat production in the Mediterranean region. In Morocco, these forest rangelands guarantee year-round feed resources for grazing goats. They provide $80 \%$ of diet requirements of grazing animals in mountainous areas (High Atlas and Northern Morocco). Four million heads of goats (i.e., approximately $70 \%$ of the national herd) graze on forest pasturelands [1]. The silvopastoral system contributes between $68 \%$ and $100 \%$ of the incomes of farmers, playing an essential socio-economic role [2].

In Northern Morocco, there is one indigenous goat breed named Beni Arouss, which was only recently officially recognized by the Moroccan Ministry of Agriculture and Rural Development (Official Journal of Morocco; $N^{\circ}$ 6, 430; 01/2016). The mountainous forest 
rangeland constitutes the exclusive feed resources of this indigenous goat breeds. The intense meat flavor of this indigenous goat is greatly appreciated by consumers. Their lactation lasts 120 days, averaging $0.504 \mathrm{~kg}$ /goat. In addition, this breed shows excellent tolerance to diseases [3]. Published works about this indigenous goat have only explored the aspects related to its genetic characteristics [4] and the effect of alternative feed resources' incorporation on goat meat and milk production [5,6]. Domestic goats (Capra hircus) have shown better performance and adaptability in harsh environments than other domesticated ruminants [7], where they face complex feed sources dominated by heterogeneous woody species.

One of the main problems of the extensive livestock systems in Morocco is the lack of information on pasture quality and feeding behaviour of indigenous goats under grazing conditions. Despite various studies focused on the European Mediterranean countries [8-14], there is little information in the literature on the browsing behaviour of indigenous goats in the mountainous silvopastoral units. Understanding the seasonal variation of forage availability and quality, and feeding behaviour of indigenous goats is crucial to develop targeted decisions to improve feeding and grazing strategies for enhanced sustainability and performances of animal production system. In order to address this issue, this work was undertaken in a mountainous silvopastoral system of the Southern Mediterranean region (Northern Morocco) to study the seasonal variations in terms of forage availability and quality of ingested plant species and browsing behavior of indigenous grazing goats.

\section{Materials and Methods}

\subsection{Experimental Forest Pasture}

An experiment was carried out in a mountainous forest pastureland located at an altitude ranging between 250 and $550 \mathrm{~m}$ above sea level in the Beni Arouss region in Northern Morocco $\left(35^{\circ} 18^{\prime} \mathrm{N}, 5^{\circ} 34^{\prime} \mathrm{W}\right)$ (Figure 1). The climate is Mediterranean, with an annual rainfall varying between 400 and $700 \mathrm{~mm}$. Temperatures range from 3 to $14{ }^{\circ} \mathrm{C}$ in winter and from 18 to $38^{\circ} \mathrm{C}$ in summer (minimum and maximum, respectively) [15]. The pastureland is a Mediterranean forest with vegetation units from low formations of Cistus spp. (inclusive of C. crispus L., C. monspeliensis L., and C. salviifolius L.) to oak groves. Vegetation includes Quercus spp. (inclusive of Q. coccifera L., Q. ilex L., and Q. suber L.) associated with shrublands dominated by Arbutus unedo L. and Cistus spp. [16].

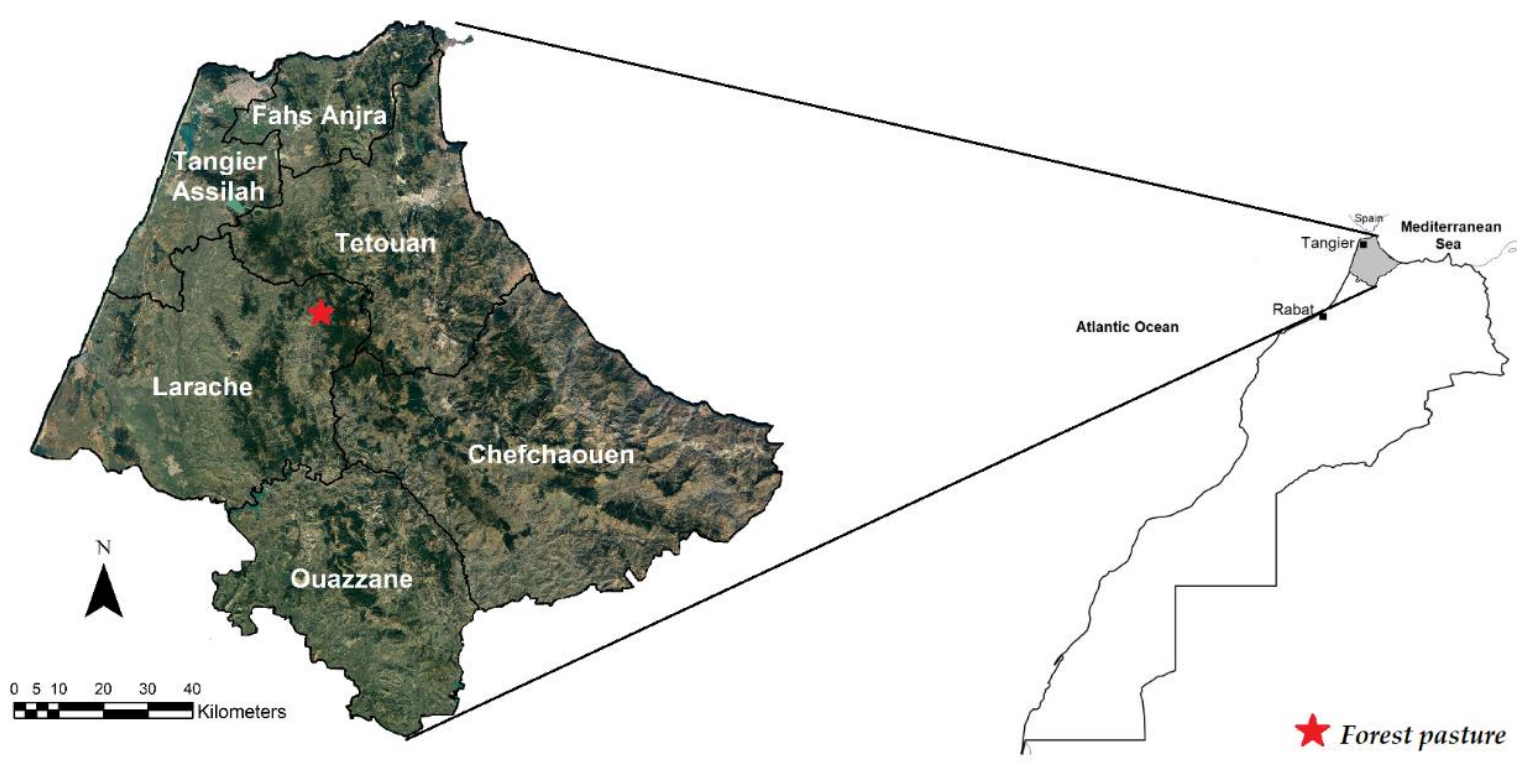

Figure 1. Location of the studied forest pasture (Northern Morocco). 


\subsection{Experimental Animals and Feeding Behaviour}

Eight indigenous Beni Arouss meat goats $(30 \pm 2.6 \mathrm{~kg}$ liveweight and $36 \pm 6$ months of age) were chosen from a local goat flock composed of 79 animals browsing in the study area. The pasture is grazed by goats during all seasons, except winter when they are confined. During winter, forest rangelands' access is very limited in the studied area, and during this time herders' trim oak tree branches (Quercus spp.) as forage for goats. The average grazing time was estimated between $7 \mathrm{~h}$ and $12 \mathrm{~h}$ depending on grazing day and season. Goats' feeding behavior was evaluated within the three seasons by the direct observation method [17]. This method seems to be better suited to recording data on diversified vegetation and at different time scales. The improved direct observation method developed by Agreil and Meuret [18] allowed for the continuous observation of the feeding behaviour of sheep and goats. The originality of this method results from its capacity to couple detailed and short-term measurements at bite scale with long-term intake balance. However, in a diversified grazing environment such as north Moroccan forest rangeland, where the number of eaten species is over twenty consumed per day, too many bite categories have to be defined, making it difficult to identify and record them in realtime. The direct observational methodology was chosen thanks to our skill of this technique. The observation procedure was realized during three consecutive grazing days over three seasons for one year: spring (green season), summer (dry season), and autumn. Data were collected by observing each experimental indigenous goat for $10 \mathrm{~min}$, with an interval of $5 \mathrm{~min}$, over the whole grazing days (morning, mid-day, and afternoon) [19]. Before starting the observation procedure, observers spent three days with goats to accustom them to the presence of an unfamiliar person, as detailed by Meuret and Provenza [20]. According to González-Pech et al. [21], the familiarization procedure was considered as successful when the observer could remain closer than $1 \mathrm{~m}$ from to the observed animal without disturbing their grazing activities. Trained observers recorded the selected plant species and the number of bites per consumed plant part, which allowed generating the total number of bites (TB). The percentage of bites per plant species $(\mathrm{TB} i, \%)$ was calculated using the following equation: $\mathrm{TB} i=\mathrm{NB} i / \mathrm{TB}$; where $\mathrm{NB} i$ is the number of observed bites of plant $i$. To determine the average mass per bite, the observer mimicked the bite mass (BM, g DM) for each plant species selected by goats (only the consumed parts of the plant) using the hand-plucking procedure (100 simulated plucks per plant per season) [22]. The hand-plucked samples were collected in special bags and taken to the laboratory in order to determine the average $\mathrm{BM}$ of each consumed species. This procedure allowed estimation of the intake rate (IR, g DM/min) and diet composition (DC, \%). The DC was reported as the percentage of each consumed species in the diet according to the following equation: $\mathrm{DC}_{i}=\left(\mathrm{NB}_{i} \times \mathrm{BM}_{i}\right) /\left(\sum_{i=1}^{n}(\mathrm{NB} \times \mathrm{BM})\right)$; where $\mathrm{DC} i$ is the proportion of the plant $i$ in the diet, $\mathrm{BM} i$ is the mean bite mass of the plant $i$, and $n$ is the number of plant species. The IR was calculated as $I R=B R \times B M$; where $B R$ is the bite rate $(B R, n / m i n)$.

\subsection{Forage Availability and Diet Selection}

Before starting the experiment, seasonal forage availability was estimated in order to calculate the seasonal diet selectivity $[23,24]$. Forage availability of each selected plants species was estimated on the basis of those effectively consumed by goats using the quadrat method $[19,25]$. Several numbers and sizes of quadrats were tested to obtain the most representative quadrat to minimize the effect of rangeland heterogeneity. Therefore, forty quadrats of $40 \mathrm{~m}^{2}(4 \mathrm{~m} \times 10 \mathrm{~m})$ for woody species and forty quadrats of $1 \mathrm{~m}^{2}$ for herbaceous species (each one embedded within one woody quadrat) were implemented seasonally in rangeland along the usual grazing paths [9]. The non-destructive method known as the reference module was used for shrubs and trees. For trees, we considered only the accessible and consumed plant parts for goats. For herbaceous, a destructive method was used, where all herbaceous biomass was cut. Biomass samples were oven-dried at $40{ }^{\circ} \mathrm{C}$ to constant weight to obtain the dry matter (DM). 
Several indexes are employed to estimate diet selectivity [26]. The selectivity measures the selection of plant species in relation to their abundance or availability in the forest rangeland. Plant species that constitute a larger proportion of the diet than their availability are considered preferred; conversely those proportionately underrepresented in the diet are avoided. The most common measure is Ivlev selectivity index (SI) as follows [27]: $\mathrm{SI}=(\%$ forage in the diet $-\%$ forage availability $) /(\%$ forage in the diet $+\%$ forage availability). According with its outcomes, diet selectivity could be classified into categories: very high $(>0.5)$, high $(0-0.5)$, low $(-0.5-0)$, and very low $(<-0.5)$ selectivity, based on goats' preferences [28].

\subsection{Forage Quality}

To determine the nutritional quality of forage in each studied season, analyses were achieved on three different hand-plucked samples of each pastoral species selected by the experimental grazing goats. The collected samples were directly conducted to the laboratory to determine the chemical composition and the digestibility parameters. All analyses were made in triplicate. The nutritional quality of plant groups is the average of the composition of pastoral species selected according to their category (herbaceous, shrubs, or trees).

\subsubsection{Chemical Composition}

The collected samples were weighed before being dried until they reached a constant weight at low temperature $\left(40^{\circ} \mathrm{C}\right)$ to avoid changes in tannins content and activity [29]. The dried samples were milled with a sieve mesh size of $1 \mathrm{~mm}$ to evaluate the chemical composition. Organic matter (OM), crude protein $(\mathrm{CP})$, and ether extract (EE) analyses were performed according to the Association of Official Analytical Chemists [30]. The OM was determined after calcination in a muffle furnace for $12 \mathrm{~h}$. Nitrogen $(\mathrm{N})$ content was measured by the Kjeldahl method and the crude protein $(\mathrm{CP})$ was calculated by multiplying $\mathrm{N}$ by 6.25. The EE were extracted by the Soxhlet method.

All fibers in the studied samples were estimated using ANKOM 200 Fiber Analyzer (ANKOM Technology, New York, NY, USA) inclusive of residual ash. The neutral detergent fiber (NDF) method was described by Mertens' [31]. The method 973.18 of AOAC [32] was used to estimate acid detergent fiber (ADF). Lignin (ADL) content was evaluated according to Robertson and Van Soest's [33] method by cellulose solubilization from ADF, using sulphuric acid. Condensed tannins (CT) were estimated by butanol- $\mathrm{HCl}$ and ferric reagents according to Porter et al. [34].

\subsubsection{Digestibility and Metabolizable Energy}

The methods for in vitro dry matter (IVDMD) and organic matter (IVOMD) digestibility are well described by Mabjeesh et al. [35]. They were determined using DAISYII Incubator (ANKOM Technology, New York, NY, USA), which tries to simulate ruminal digestion [36]. Briefly, $0.5 \mathrm{~g}$ of each sample was placed in ANKOM filter bags (F57) and was incubated at $39.5^{\circ} \mathrm{C}$ in jars ( $24 \mathrm{bags} / \mathrm{jar}$ ), which contained an inoculum. This inoculum was a mixture of $4 / 5$ volume of artificial saliva and $1 / 5$ of rumen liquor. After $48 \mathrm{~h}$ of incubation, IVDMD and IVOMD were calculated by weighing the residuals DM and OM comparing to initial incubated quantities. The used rumen liquor in the inoculum was collected from five goats at a local slaughterhouse as widely described by El Otmani et [37]. These goats grazed in a forest pastureland similar to the studied area.

The metabolizable energy (ME; MJ / kg DM) of the studied plants were predicted based on the digestibility results, according to the following formula suggested by AOAC [32]: $\mathrm{ME}=0.17 \times \mathrm{DMD}-2$, where DMD is the dry matter digestibility in $\%$.

\subsection{Statistical Analysis}

Data analyses were performed using SAS software v9.4 (SAS Inst. Cary, NC, USA). Before analyses, data expressed as percentage were arcsine-square root-transformed to nor- 
malize their distribution [38]. Bite mass was analyzed using two-way analysis of variance (ANOVA) with either plant species $(n=15)$ or plant groups (i.e., herbaceous, shrubs and trees), seasons (i.e., spring, summer, and autumn), and their interaction. Forage availability and quality (chemical composition, digestibility, and metabolizable energy) were analyzed using a general linear model (GLM) procedure of SAS in a factorial structure. They were compared between plant species or plant groups and seasons and their interaction. Feeding behaviour data (selectivity, bite rate, intake rate, and diet composition) were analyzed according to the PROC MIXED procedure of SAS [39] with the daily observation on each goat as experimental unit. Differences in feeding behaviour were assessed considering the effects of plant species or plant groups, seasons and their interaction. The individual goat was considered as a random effect to prevent this variance from being incorporated in the error term of the analysis. Pearson correlation analysis was used to establish the relationships between chemical component variables, digestibility, intake, and selection. For all variables analyzed, the significance level was declared at $p<0.05$. In case of significant effect, means were compared using the Tukey's test.

\section{Results}

\subsection{Forage Availability and Diet Selection}

The season affected the average forage availability of the studied pasture $(p<0.001)$. The spring recorded the higher forage production significantly in comparison with the summer and autumn (Figure 2A).
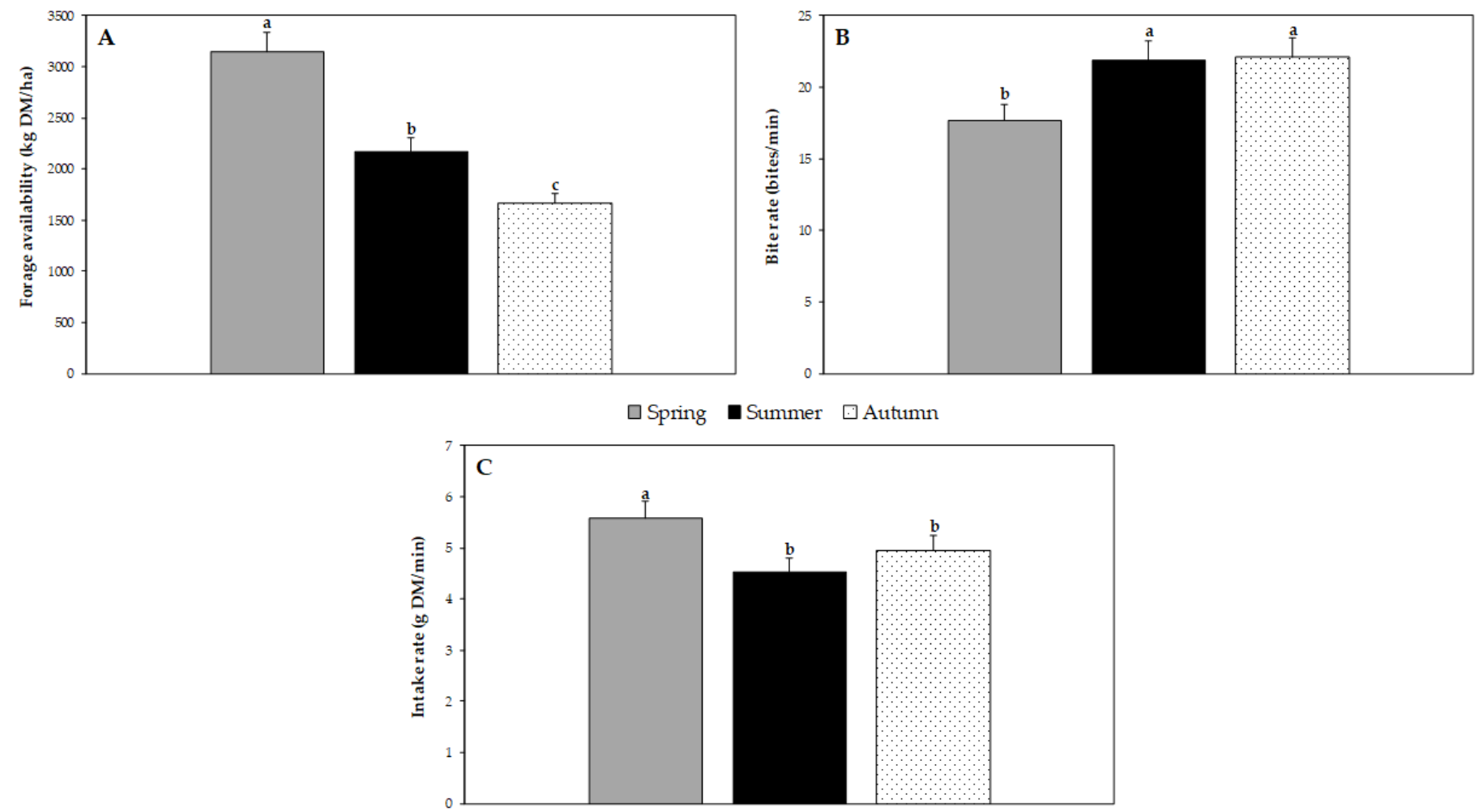

Figure 2. Seasonal variation of forage availability (A), bite rate (B), and intake rate (C) of indigenous goats grazing in a Mediterranean forest rangeland. Means with different letters $(\mathrm{a}-\mathrm{c})$ indicate significant differences $(p<0.05)$.

Three distinct groups of plant species dominated the forest vegetation and composed the goats' diet, namely: herbaceous plants (mainly Anthemis cotula L., Brachypodium distachyon L., Bromus rigidus Roth, Calamintha nepeta (L.) Kuntze, Cynodon dactylon (L.) Pers., Eryngium tricuspidatum L., Lythrum junceum Banks and Sol., Rumex bucephalophorus L.), shrubs (Arbutus unedo L., Calicotome villosa (Poir.) Link, Cistus spp., Erica arborea L., La- 
vandula stoechas L., Myrtus communis L., Phillyrea media L., Pistacia lentiscus L., and Rubus ulmifolius Schott.), and trees (Quercus spp. and Olea europaea subsp. O. europaea L. var. sylvestris (Mill) Lehr).

The seasonal variation of forage availability and selectivity towards shrubs, trees, and plant groups of indigenous grazing goats are detailed in Tables $1-3$, respectively.

Table 1. Seasonal variation of forage availability, feeding behaviour, and selectivity towards shrubs of indigenous goats grazing in a Mediterranean forest rangeland of Northern Morocco.

\begin{tabular}{|c|c|c|c|c|c|}
\hline & $\begin{array}{c}\text { Availability } \\
(\%)\end{array}$ & $\begin{array}{l}\text { Selectivity } \\
\text { Index }\end{array}$ & $\begin{array}{c}\text { Bite Mass } \\
\text { (g DM/Bite) }\end{array}$ & $\begin{array}{c}\text { Total Bites } \\
\text { (\%) }\end{array}$ & $\begin{array}{c}\text { Diet Composition } \\
(\%)\end{array}$ \\
\hline \multicolumn{6}{|l|}{ Spring } \\
\hline Arbutus unedo & $31.4^{\mathrm{c}}$ & $-0.983^{n}$ & $0.119^{\mathrm{j}}$ & $0.619 \mathrm{mno}$ & $0.234^{\operatorname{lmno}}$ \\
\hline Cistus crispus & $12.9 \mathrm{de}$ & $0.549^{c}$ & $0.340^{\mathrm{a}}$ & $26.1^{\mathrm{a}}$ & $25.9^{\mathrm{a}}$ \\
\hline Cistus monspeliensis & 13.9 de & $0.255^{\mathrm{d}}$ & $0.323^{b}$ & $23.6^{\mathrm{b}}$ & $23.9^{b}$ \\
\hline Cistus salviifolius & $18.3^{\mathrm{d}}$ & $0.045^{\mathrm{e}}$ & $0.349^{a}$ & $21.8^{\mathrm{cd}}$ & $24.3^{b}$ \\
\hline Calicotome villosa & $1.55^{\mathrm{ij}}$ & $-0.919 \operatorname{lmn}$ & $0.110^{\mathrm{jk}}$ & $0.185^{\text {no }}$ & $0.064^{\text {no }}$ \\
\hline Erica arborea & $16.6^{\mathrm{e}}$ & $-0.784^{\mathrm{jkl}}$ & 0.222 ef & $4.43^{1}$ & $2.74^{\mathrm{i}}$ \\
\hline Lavandula stoechas & $3.45 \mathrm{ghi}$ & $0.757^{\mathrm{b}}$ & $0.319^{b}$ & $22.2^{\mathrm{cd}}$ & $22.5^{\mathrm{b}}$ \\
\hline Myrtus communis & $0.033^{\mathrm{kl}}$ & $0.650^{\mathrm{b}}$ & $0.080 \mathrm{mn}$ & 0.319 no & $0.078^{\text {no }}$ \\
\hline Pistacia lentiscus & $1.72 \mathrm{ijk}$ & $-0.822 \mathrm{klmn}$ & $0.091 \mathrm{~lm}$ & $0.505^{\text {no }}$ & $0.146 \mathrm{mno}$ \\
\hline Phillyrea media & $0.034 \mathrm{kl}$ & $0.672^{b}$ & $0.070^{n}$ & $0.255^{\text {no }}$ & $0.057^{\text {no }}$ \\
\hline Rubus ulmifolius & $0.010^{1}$ & $-0.984^{n}$ & $0.050^{\circ}$ & $0.006^{\mathrm{o}}$ & $0.001^{\mathrm{o}}$ \\
\hline SEM & 0.057 & 0.025 & 0.004 & 0.402 & 0.043 \\
\hline \multicolumn{6}{|l|}{ Summer } \\
\hline Arbutus unedo & $12.02 \mathrm{gh}$ & $-0.470^{\mathrm{h}}$ & 0.220 ef & $12.8^{\mathrm{i}}$ & $14.6^{\mathrm{e}}$ \\
\hline Cistus crispus & $10.5^{\text {ef }}$ & $-0.904 \operatorname{lmn}$ & $0.110^{\mathrm{jk}}$ & $1.29 \mathrm{mno}$ & $0.75^{\mathrm{kl}}$ \\
\hline Cistus monspeliensis & $26.8^{c}$ & $-0.957 \mathrm{mn}$ & $0.101 \mathrm{kl}$ & $1.01 \mathrm{mno}$ & $0.529 \mathrm{klm}$ \\
\hline Cistus salviifolius & $42.7^{\mathrm{a}}$ & $-0.961 \mathrm{mn}$ & $0.110^{\mathrm{jk}}$ & $1.32 \mathrm{mn}$ & $0.760^{\mathrm{k}}$ \\
\hline Calicotome villosa & $2.11^{\mathrm{hi}}$ & $0.618^{b c}$ & 0.170 gh & $9.33^{\mathrm{j}}$ & $8.25^{\mathrm{g}}$ \\
\hline Erica arborea & $1.71^{\mathrm{ijk}}$ & -0.139 de & $0.179 \mathrm{~g}$ & $16.7 \mathrm{gh}$ & $15.7^{\mathrm{e}}$ \\
\hline Lavandula stoechas & 3.27 ghi & $-0.810 \mathrm{jklm}$ & $0.100 \mathrm{kl}$ & $1.28^{\mathrm{mno}}$ & $0.673^{\mathrm{kl}}$ \\
\hline Myrtus communis & $0.338^{\mathrm{jkl}}$ & $0.974^{\mathrm{a}}$ & $0.260^{c}$ & $17.5^{\mathrm{g}}$ & $23.6^{c}$ \\
\hline Pistacia lentiscus & $0.197^{\mathrm{jkl}}$ & $0.734^{b}$ & $0.242^{d}$ & $18.7^{\mathrm{f}}$ & $23.4^{\mathrm{c}}$ \\
\hline Phillyrea media & $0.040^{\mathrm{jkl}}$ & $0.969^{\mathrm{a}}$ & $0.147^{\mathrm{i}}$ & $12.7^{\mathrm{i}}$ & $7.26^{\mathrm{g}}$ \\
\hline Rubus ulmifolius & $0.329 \mathrm{jkl}$ & $0.740^{\mathrm{b}}$ & $0.120^{j}$ & $7.32^{k}$ & $4.54^{\mathrm{h}}$ \\
\hline SEM & 0.075 & 0.029 & 0.002 & 2.57 & 0.031 \\
\hline \multicolumn{6}{|l|}{ Autumn } \\
\hline Arbutus unedo & $30.7^{b c}$ & $-0.200 \mathrm{fg}$ & $0.215^{f}$ & $17.3^{\mathrm{e}}$ & $18.9^{\mathrm{d}}$ \\
\hline Cistus crispus & 2.77 ghi & $-0.890 \operatorname{lmn}$ & $0.093^{\mathrm{lm}}$ & $1.64^{\mathrm{m}}$ & $0.788^{\mathrm{kl}}$ \\
\hline Cistus monspeliensis & $5.89 \mathrm{fg}$ & $-0.962 \mathrm{~lm}$ & $0.090 \mathrm{~lm}$ & $1.01 \mathrm{mno}$ & $0.470 \mathrm{klmn}$ \\
\hline Cistus salviifolius & $12.5^{\mathrm{de}}$ & $-0.971 \mathrm{mn}$ & $0.105^{\mathrm{jkl}}$ & $1.09 \mathrm{mno}$ & $0.552 \mathrm{klm}$ \\
\hline Calicotome villosa & $0.218^{\mathrm{jkl}}$ & $0.600^{b c}$ & $0.165 \mathrm{gh}$ & $0.902 \mathrm{mno}$ & $0.725 \mathrm{klm}$ \\
\hline Erica arborea & $41.8^{\mathrm{ab}}$ & $-0.265^{g}$ & $0.167 \mathrm{gh}$ & $20.3^{b c}$ & $18.0^{\mathrm{d}}$ \\
\hline Lavandula stoechas & 2.91 ghi & $-0.518^{h i}$ & $0.090 \mathrm{~lm}$ & $3.66^{1}$ & $1.68^{j}$ \\
\hline Myrtus communis & $0.150^{\mathrm{jkl}}$ & $0.978^{a}$ & $0.242^{\mathrm{d}}$ & $19.3^{d}$ & $23.5^{c}$ \\
\hline Pistacia lentiscus & $3.00 \mathrm{ghi}$ & $0.762^{b}$ & 0.233 de & $20.1^{\mathrm{cd}}$ & $23.3^{c}$ \\
\hline Phillyrea media & $0.078^{\mathrm{jkl}}$ & $0.947^{\mathrm{a}}$ & $0.163^{h}$ & $13.6^{\mathrm{h}}$ & $11.2^{\mathrm{f}}$ \\
\hline Rubus ulmifolius & $0.037 \mathrm{kl}$ & $0.093^{\mathrm{e}}$ & $0.144^{\mathrm{i}}$ & $1.13^{\mathrm{nm}}$ & $0.831 \mathrm{kl}$ \\
\hline SEM & 0.069 & 0.028 & 0.002 & 0.328 & 0.035 \\
\hline \multicolumn{6}{|l|}{$p$-Value } \\
\hline Season & 0.005 & $<0.001$ & $<0.001$ & $<0.001$ & 0.002 \\
\hline Plant species & $<0.001$ & $<0.001$ & $<0.001$ & $<0.001$ & $<0.001$ \\
\hline Season $\times$ Plant species & $<0.001$ & $<0.001$ & $<0.001$ & $<0.001$ & $<0.001$ \\
\hline
\end{tabular}

SEM, standard error of the mean. Within a column, values with different letters are significantly different $(p<0.05)$. 
Table 2. Seasonal variation of forage availability, feeding behaviour, and selectivity towards trees of indigenous goats grazing in a Mediterranean forest rangeland of Northern Morocco.

\begin{tabular}{|c|c|c|c|c|c|}
\hline & $\begin{array}{c}\text { Availability } \\
\text { (\%) }\end{array}$ & $\begin{array}{l}\text { Selectivity } \\
\text { Index }\end{array}$ & $\begin{array}{c}\text { Bite Mass } \\
\text { (g DM/bite) }\end{array}$ & $\begin{array}{c}\text { Total Bites } \\
\text { (\%) }\end{array}$ & $\begin{array}{c}\text { Diet Composition } \\
(\%)\end{array}$ \\
\hline \multicolumn{6}{|l|}{ Spring } \\
\hline Olea europaea & $9.48^{c}$ & $-0.655^{\mathrm{de}}$ & $0.071^{\mathrm{g}}$ & $13.1^{\mathrm{d}}$ & $23.6^{b}$ \\
\hline Quercus coccifera & $20.9^{b}$ & $-0.929^{f}$ & $0.071^{\mathrm{g}}$ & $2.09^{f}$ & $3.52^{\mathrm{e}}$ \\
\hline Quercus ilex & $28.6^{\mathrm{b}}$ & -0.793 ef & $0.060^{\mathrm{h}}$ & $10.1^{\mathrm{e}}$ & $16.0^{\mathrm{cd}}$ \\
\hline Quercus suber & $40.9^{a}$ & $-0.464^{\mathrm{d}}$ & $0.029^{\mathrm{i}}$ & $74.8^{\mathrm{a}}$ & $56.9^{a}$ \\
\hline SEM & 4.95 & 0.027 & 0.002 & 2.66 & 0.271 \\
\hline \multicolumn{6}{|l|}{ Summer } \\
\hline Olea europaea & $9.46^{\mathrm{c}}$ & $0.979^{\mathrm{a}}$ & $0.191^{\mathrm{c}}$ & $26.6^{c}$ & $20.6^{b}$ \\
\hline Quercus coccifera & $19.1^{b}$ & $0.868^{a b}$ & $0.139^{f}$ & $10.8^{\mathrm{e}}$ & $18.2^{\mathrm{C}}$ \\
\hline Quercus ilex & $25.2^{b}$ & $0.619^{\mathrm{c}}$ & $0.139^{f}$ & $16.9^{\mathrm{d}}$ & $9.60^{\mathrm{d}}$ \\
\hline Quercus suber & $46.2^{\mathrm{a}}$ & $0.906^{\mathrm{ab}}$ & $0.282^{\mathrm{a}}$ & $45.6^{\mathrm{b}}$ & $51.6^{\mathrm{a}}$ \\
\hline SEM & 4.00 & 0.013 & 0.004 & 0.928 & 1.01 \\
\hline \multicolumn{6}{|l|}{ Autumn } \\
\hline Olea europaea & $5.00^{c}$ & $0.714^{b c}$ & $0.205^{b}$ & $15.6^{\mathrm{d}}$ & $14.9^{\mathrm{cd}}$ \\
\hline Quercus coccifera & $24.3^{b}$ & $0.572^{c}$ & $0.171^{d}$ & $18.6^{\mathrm{cd}}$ & $15.5^{\mathrm{cd}}$ \\
\hline Quercus ilex & $24.5^{b}$ & $0.652^{c}$ & $0.153^{\mathrm{e}}$ & $23.9^{c}$ & $18.2^{\mathrm{c}}$ \\
\hline Quercus suber & $46.2^{\mathrm{a}}$ & $0.941^{\mathrm{a}}$ & $0.289^{a}$ & $41.8^{\mathrm{b}}$ & $51.3^{\mathrm{a}}$ \\
\hline SEM & 7.83 & 0.029 & 0.003 & 0.845 & 0.109 \\
\hline \multicolumn{6}{|l|}{$p$-Value } \\
\hline Season & $<0.001$ & $<0.001$ & $<0.001$ & $<0.001$ & $<0.001$ \\
\hline Plant species & 0.008 & $<0.001$ & $<0.001$ & $<0.001$ & $<0.001$ \\
\hline Season $\times$ Plant species & 0.956 & $<0.001$ & $<0.001$ & $<0.001$ & $<0.001$ \\
\hline
\end{tabular}

SEM, standard error of the mean. Within a column, values with different letters are significantly different $(p<0.05)$.

Table 3. Seasonal variation of forage availability, feeding behaviour, and selectivity towards plant groups of indigenous goats grazing in a Mediterranean forest rangeland of Northern Morocco.

\begin{tabular}{|c|c|c|c|c|c|}
\hline & $\begin{array}{l}\text { Availability } \\
(\%)\end{array}$ & $\begin{array}{l}\text { Selectivity } \\
\text { Index }\end{array}$ & $\begin{array}{c}\text { Bite Mass } \\
\text { (g DM/bite) }\end{array}$ & $\begin{array}{c}\text { Total Bites } \\
(\%)\end{array}$ & $\begin{array}{c}\text { Diet Composition } \\
(\%)\end{array}$ \\
\hline \multicolumn{6}{|l|}{ Spring } \\
\hline Herbaceous & $8.49^{c}$ & $0.079^{b}$ & $0.361^{\mathrm{a}}$ & $8.10^{\mathrm{d}}$ & $10.7^{\mathrm{d}}$ \\
\hline Shrubs & $90.10^{b}$ & $-0.383^{d}$ & $0.188^{c}$ & $88.9^{a}$ & $88.9^{a}$ \\
\hline Trees & $1.41 \mathrm{de}$ & $-0.710^{\mathrm{e}}$ & $0.058^{f}$ & $2.99^{e}$ & $0.37^{\mathrm{f}}$ \\
\hline SEM & 3.74 & 0.018 & 0.007 & 2.70 & 2.78 \\
\hline \multicolumn{6}{|l|}{ Summer } \\
\hline Herbaceous & $8.91^{\mathrm{c}}$ & $-0.466^{\mathrm{d}}$ & $0.110^{\mathrm{e}}$ & $3.12^{\mathrm{e}}$ & $1.66^{\mathrm{e}}$ \\
\hline Shrubs & $89.02^{b}$ & $-0.019^{c}$ & $0.160^{d}$ & $67.9^{b}$ & $63.6^{\mathrm{b}}$ \\
\hline Trees & $2.07 \mathrm{~d}$ & $0.843^{a}$ & $0.188^{c}$ & $28.9^{\mathrm{c}}$ & $34.7^{\mathrm{c}}$ \\
\hline SEM & 3.66 & 0.038 & 0.002 & 1.84 & 1.74 \\
\hline \multicolumn{6}{|l|}{ Autumn } \\
\hline Herbaceous & $2.56^{\mathrm{d}}$ & $-0.037^{\mathrm{c}}$ & $0.105^{\mathrm{e}}$ & $5.56^{\mathrm{de}}$ & $1.86^{\mathrm{e}}$ \\
\hline Shrubs & $96.84^{\mathrm{a}}$ & $-0.165^{\mathrm{d}}$ & $0.155^{\mathrm{d}}$ & $69.1^{b}$ & $67.7^{\mathrm{b}}$ \\
\hline Trees & $0.600^{\mathrm{e}}$ & $0.720^{a}$ & $0.204^{b}$ & $25.4^{\mathrm{c}}$ & $30.4^{\mathrm{c}}$ \\
\hline SEM & 4.12 & 0.029 & 0.003 & 0.467 & 1.87 \\
\hline \multicolumn{6}{|l|}{$p$-Value } \\
\hline Season & 0.335 & $<0.001$ & $<0.001$ & $<0.001$ & $<0.001$ \\
\hline Plant groups & $<0.001$ & $<0.001$ & $<0.001$ & $<0.001$ & $<0.001$ \\
\hline Season $\times$ Plant groups & $<0.001$ & $<0.001$ & $<0.001$ & $<0.001$ & $<0.001$ \\
\hline
\end{tabular}

SEM, standard error of the mean. Within a column, values with different letters are significantly different $(p<0.05)$. 
Forage availability varied with the season $(p<0.01)$, species, or plant groups $(p<0.01)$ and their interaction $(p<0.001)$, except for the effects of the interaction of season and species on tree species availability $(p=0.956)$ and the season effect on plant group availability $(p=0.335)$. Shrubs were the most available forage, with C. salviifolius $(42.7 \%)$ in summer, E. arborea (41.8\%) in autumn, and A. unedo (31.4\%) in spring.

Diet selection was affected by season, species or plant groups and their interaction $(p<0.001)$. The shrubs M. communis and P. media were highly selected across all seasons. C. villosa, P. lentiscus, and R. ulmifolius were mostly selected in summer and autumn. The same tendency was observed for the selectivity of each tree species (Quercus spp. and $O$. europaea). Cistus spp. and L. stoechas had high selectivity only in spring. E. arborea was highly selected only during the summer. All plant groups had low selectivity in all three seasons, apart from herbaceous in spring and the tree group in summer and autumn.

\subsection{Feeding Behaviour}

The season affected the average of bite and intake rates $(p<0.05$; Figure $2 \mathrm{~B}, \mathrm{C})$. On the one hand, the higher biting rate was recorded equally during summer and autumn (about $22 \mathrm{bites} / \mathrm{min}$ ). On the other hand, the higher intake rate was recorded during spring (5.57 $\mathrm{g}$ $\mathrm{DM} / \mathrm{min})$.

Data on the seasonal variation of feeding behaviour (bite mass, total bites, and diet composition) towards shrubs, trees, and plant groups of indigenous grazing goats are detailed in Tables 1-3, respectively. All measured parameters were affected by season $(p<0.01)$, species, or plant groups $(p<0.001)$, and their interaction $(p<0.001)$. Overall, during summer and autumn, the highest values of feeding behaviour parameters driving intake rates (BM, TB, and DC) were recorded on A. unedo, M. communis, and P. lentiscus for shrubs and on O. europaea and $Q$. suber for trees. During spring, the highest values were observed on Cistus spp. and L. stoechas.

The trees group registered the largest values of BM in autumn $(0.204 \mathrm{~g} \mathrm{DM} / \mathrm{bite})$ and summer (0.188 g DM/bite), and the smallest values in spring (0.058 g DM/bite). During spring, the highest BM was observed in herbaceous $(0.361 \mathrm{~g} \mathrm{DM} / \mathrm{bite})$. For the shrubs group, the BM varied from 0.155 to $0.188 \mathrm{~g} \mathrm{DM} / \mathrm{bite}$, and the total percentage of bites varied from 67.9 to $88.9 \%$. The DC of shrubs ranged from 63.6 to $88.9 \%$ across all studied seasons.

\subsection{Forage Quality}

The outcomes for the seasonal variation in the chemical composition, IVOMD, and ME of selected plant groups by indigenous grazing goats are presented in Table 4 . The detailed nutritive quality of plant groups in the three seasons shows that half of the parameters were affected by season (DM, OM, CP, IVOMD, and ME; $p<0.05)$, except for EE, fibers, and CT $(p>0.05)$. Additionally, as expected, the forage quality differed according to the plant group even if for the EE concentrations only tended to differ $(p=0.093)$. The significant interaction effects of season and plant groups were obtained only for $\mathrm{OM}(p=0.036)$ and $\mathrm{CP}(p=0.023)$ contents. The DM level was higher for all plant groups in the summer. The OM content was lower in herbaceous during the three seasons compared to shrubs and trees. The lowest and the highest CP contents were recorded in herbaceous during autumn $(66.4 \mathrm{~g} / \mathrm{kg} \mathrm{DM})$ and spring $(169 \mathrm{~g} / \mathrm{kg} \mathrm{DM})$, respectively. The EE levels of all plant groups were below $48 \mathrm{~g} / \mathrm{kg}$ DM. Shrubs recorded the lowest concentrations of NDF $(402 \mathrm{~g} / \mathrm{kg}$ $\mathrm{DM})$ and ADF (274 $\mathrm{g} / \mathrm{kg} \mathrm{DM})$ during spring while they had the highest levels of ADL $(187 \mathrm{~g} / \mathrm{kg} \mathrm{DM})$ during the summer. Herbaceous had the highest ADF content $(382 \mathrm{~g} / \mathrm{kg}$ $\mathrm{DM})$ in summer and the lowest ADL $(61.3 \mathrm{~g} / \mathrm{kg} \mathrm{DM})$ in spring. The CT levels showed a wide variation, ranging from $2.67 \mathrm{~g} / \mathrm{kg}$ DM in herbaceous plants in spring to $86.6 \mathrm{~g} / \mathrm{kg}$ $\mathrm{DM}$ in shrubs in summer. Both IVOMD and ME had recorded the highest contents in herbaceous during spring $(823 \mathrm{~g} / \mathrm{kg}$ and $12.2 \mathrm{MJ} / \mathrm{kg}$, respectively). Shrubs and trees registered the lowest levels of IVOMD (less than $500 \mathrm{~g} / \mathrm{kg}$ ) and ME (less than 7.2 MJ/kg) 
during autumn and summer. Generally, herbaceous group had the highest IVOMD and ME independently of the season compared to other plant groups.

Table 4. Seasonal variation in the chemical composition (g/kg DM), IVOMD (g/kg), and ME (MJ/kg $\mathrm{DM}$ ) of selected plant groups by indigenous Beni Arouss goats grazing a Mediterranean forest rangeland of Northern Morocco.

\begin{tabular}{|c|c|c|c|c|c|c|c|c|c|c|}
\hline & DM & OM & $\mathrm{CP}$ & EE & NDF & ADF & ADL & CT & IVOMD & ME \\
\hline \multicolumn{11}{|l|}{ Spring } \\
\hline Herbaceous & $472^{b c}$ & $915^{b}$ & $169^{a}$ & $20.5^{\mathrm{a}}$ & $529^{a b}$ & $344^{a b}$ & $61.3^{c}$ & $2.67^{b}$ & $823^{a}$ & $12.2^{\mathrm{a}}$ \\
\hline Shrubs & $466^{b c}$ & $940^{a b}$ & $109^{b}$ & $45.3^{\mathrm{a}}$ & $402^{c}$ & $274^{b}$ & $145^{\mathrm{ab}}$ & $65.4^{\mathrm{ab}}$ & $575^{d}$ & $8.10^{\mathrm{d}}$ \\
\hline Trees & $548^{a b}$ & $959^{a}$ & $95.2^{b c}$ & $39.5^{\mathrm{a}}$ & $511^{a b}$ & $349^{a b}$ & $164^{\mathrm{a}}$ & $42.6^{\mathrm{ab}}$ & $547^{\text {de }}$ & $7.86^{\mathrm{d}}$ \\
\hline SEM & 15.6 & 4.19 & 4.41 & 4.27 & 11.3 & 8.99 & 6.92 & 8.26 & 14.0 & 0.23 \\
\hline \multicolumn{11}{|l|}{ Summer } \\
\hline Herbaceous & $628^{a}$ & $878^{c}$ & $86.6^{b c}$ & $23.1^{\mathrm{a}}$ & $581^{a}$ & $382^{a}$ & $79.9^{b c}$ & $3.70^{b}$ & $652^{c}$ & $9.60^{c}$ \\
\hline Shrubs & $557^{\mathrm{ab}}$ & $947^{\mathrm{ab}}$ & $89.7^{b c}$ & $47.8^{a}$ & $453^{b c}$ & $304^{a b}$ & $187^{\mathrm{a}}$ & $86.6^{a}$ & $460^{f}$ & $6.29^{\mathrm{e}}$ \\
\hline Trees & $597^{a}$ & $947^{a b}$ & $77.1^{b c}$ & $47.9^{\mathrm{a}}$ & $508^{a b}$ & $340^{a b}$ & $162^{\mathrm{a}}$ & $55.7^{\mathrm{ab}}$ & $459^{f}$ & $6.52^{\mathrm{e}}$ \\
\hline SEM & 13.7 & 5.24 & 4.54 & 4.69 & 12.9 & 10.3 & 10.8 & 9.14 & 10.4 & 0.18 \\
\hline \multicolumn{11}{|l|}{ Autumn } \\
\hline Herbaceous & $537^{a b c}$ & $847^{\mathrm{d}}$ & $66.4^{c}$ & $21.4^{\mathrm{a}}$ & $455^{b c}$ & $281^{\mathrm{b}}$ & $64.2^{c}$ & $3.30^{b}$ & $724^{b}$ & $10.8^{b}$ \\
\hline Shrubs & $429^{c}$ & $942^{a b}$ & $90.3^{b c}$ & $37.2^{\mathrm{a}}$ & 449 bc & $311^{a b}$ & $179^{a}$ & $78.6^{a}$ & $458^{f}$ & $6.33^{\mathrm{e}}$ \\
\hline Trees & $563^{a b}$ & $951^{\mathrm{a}}$ & $78.1^{\mathrm{bc}}$ & $36.2^{\mathrm{a}}$ & $489^{b}$ & $338^{a b}$ & $164^{\mathrm{a}}$ & $49.7^{\mathrm{ab}}$ & $496^{\text {ef }}$ & $7.15^{\mathrm{de}}$ \\
\hline SEM & 15.3 & 4.62 & 4.79 & 3.18 & 10.3 & 10.3 & 9.72 & 8.51 & 11.4 & 0.20 \\
\hline \multicolumn{11}{|l|}{$p$-Value } \\
\hline Season & 0.003 & 0.020 & $<0.001$ & 0.669 & 0.089 & 0.295 & 0.582 & 0.809 & $<0.001$ & $<0.001$ \\
\hline Plant groups & $<0.001$ & $<0.001$ & 0.039 & 0.093 & $<0.001$ & 0.001 & $<0.001$ & $<0.001$ & $<0.001$ & $<0.001$ \\
\hline Season $\times$ Plant groups & 0.230 & 0.036 & 0.023 & 0.983 & 0.065 & 0.150 & 0.577 & 0.993 & 0.119 & 0.162 \\
\hline
\end{tabular}

ADF, acid detergent fiber; ADL, acid detergent lignin; CP, crude protein; CT, condensed tannins; DM, dry matter EE, ether extract; IVOMD, in vitro organic matter digestibility; ME, metabolizable energy; NDF, neutral detergent fiber; OM, organic matter; SEM, standard error of the mean. Within a column, values with different letters are significantly different $(p<0.05)$.

Information for the seasonal variation in the chemical composition, IVOMD, and ME of selected shrub species by indigenous grazing goats is presented in Table 5. Regarding shrubs, the quality of the forage was influenced by species, but also season and their interaction $(p<0.001)$, except for OM content which was not affected by season $(p=0.071)$. The DM ranged between 227 and $691 \mathrm{~g} / \mathrm{kg}$ DM and the highest values were observed in the summer while the OM content recorded more than $848 \mathrm{~g} / \mathrm{kg}$ DM. The CP level varied from $53.3 \mathrm{~g} / \mathrm{kg}$ DM for E. arborea in summer to $197 \mathrm{~g} / \mathrm{kg}$ DM for C. villosa in autumn, which also had the higher $\mathrm{CP}$ content $(>187 \mathrm{~g} / \mathrm{kg} \mathrm{DM})$ among all consumed shrub species in spring and summer. The lowest and highest contents of EE were observed during spring in $C$. crispus $(15.9 \mathrm{~g} / \mathrm{kg} \mathrm{DM})$ and in E. arborea $(96.1 \mathrm{~g} / \mathrm{kg} \mathrm{DM})$, respectively. Concerning fibers, the highest NDF and ADF contents were recorded in C. villosa during the three seasons and the highest ADL content in E. arborea during the summer. Although, the lowest concentrations of ADF and ADL were noted in R. ulmifolius during autumn, while the lowest NDF content was in C. crispus during the three seasons. The CT content ranged between $1.93 \mathrm{~g} / \mathrm{kg} \mathrm{DM}$ in L. stoechas (autumn) and $206 \mathrm{~g} / \mathrm{kg}$ DM in P. lentiscus (summer). The C. villosa in autumn was the less digestible species with IVOMD of $359 \mathrm{~g} / \mathrm{kg}$ and L. stoechas in spring was the more digestible with $717 \mathrm{~g} / \mathrm{kg}$. Overall, the highest values of IVOMD were observed in spring. E. arborea had the lowest ME with $4.41 \mathrm{MJ} / \mathrm{kg} \mathrm{DM}$ in the summer. However, the highest energy level was observed in L. stoechas in spring with $10.4 \mathrm{MJ} / \mathrm{kg}$ DM.

Data on the seasonal variation in the chemical composition, IVOMD $(\mathrm{g} / \mathrm{kg})$, and ME of selected tree species by indigenous grazing goats could be seen in Table 6 . All measured parameters depended significantly to the season $(p<0.05)$, species $(p<0.001)$ and their interaction $(p<0.001)$, except for CP and ADL contents which were similar between species $(p=0.144)$ and seasons $(p=0.507)$, respectively. The O. europaea had the highest moisture content compared to the other trees in all studied seasons. However, the highest DM was in Q. coccifera during summer. The OM levels varied from 914 to $970 \mathrm{~g} / \mathrm{kg} \mathrm{DM}$. The CP concentration ranged from $66.6 \mathrm{~g} / \mathrm{kg}$ DM in Q. coccifera (summer) to $109 \mathrm{~g} / \mathrm{kg} D M$ in $Q$. ilex (spring). The lowest level of EE content was $18.3 \mathrm{~g} / \mathrm{kg}$ DM in Q. coccifera (spring) and 
the highest level was $121 \mathrm{~g} / \mathrm{kg}$ DM in O. europaea (summer). The NDF, ADF and ADL registered the highest contents in Q. suber ( $589 \mathrm{~g} / \mathrm{kg}$ DM; spring), Q. coccifera (401 g/ $/ \mathrm{kg} \mathrm{DM}$; autumn), and Q. ilex (191 g/ kg DM; spring), respectively. In the three seasons, O. europea had the lowest NDF and ADF contents. The ADL content was the lowest in Q. coccifera during spring. The CT content was lower and higher during summer in O. europaea and $Q$. suber, respectively. Both IVOMD and ME recorded the highest concentrations in Q. coccifera during spring. Generally, the summer recorded the lowest contents of IVOMD and ME, except for O. europaea that had the smallest values in spring.

Table 5. Seasonal variation in the chemical composition (g/ kg DM), IVOMD (g/kg), and ME (MJ/kg $\mathrm{DM}$ ) of selected shrub species by indigenous Beni Arouss goats grazing a Mediterranean forest rangeland of Northern Morocco.

\begin{tabular}{|c|c|c|c|c|c|c|c|c|c|c|}
\hline & DM & OM & $\mathrm{CP}$ & $\mathrm{EE}$ & NDF & ADF & ADL & $\mathrm{CT}$ & IVOMD & ME \\
\hline \multicolumn{11}{|l|}{ Spring } \\
\hline Arbutus unedo & 572 efg & 961 abcde & $77.8^{\mathrm{jklmn}}$ & $71.8^{\mathrm{b}}$ & $348^{\text {no }}$ & 248 klmnop & $112 \mathrm{hij}$ & 92.5 hij & $638^{\mathrm{b}}$ & $9.14^{\mathrm{b}}$ \\
\hline Cistus crispus & $415 \mathrm{pq}$ & 954 abcde & $112^{\text {cde }}$ & $15.9^{\mathrm{k}}$ & $303 \mathrm{p}$ & $267^{\mathrm{jklm}}$ & $107^{\text {hijk }}$ & $16.4 \mathrm{pq}$ & $696^{a}$ & $9.92^{\mathrm{a}}$ \\
\hline Cistus monspeliensis & $583^{\text {def }}$ & 900 hi & $97.7^{\text {efgh }}$ & $55.9^{c}$ & $372 \mathrm{mn}$ & $217 \mathrm{pqr}$ & $205^{\text {de }}$ & $43.7^{\text {no }}$ & $593^{\mathrm{cd}}$ & $8.38^{\mathrm{cd}}$ \\
\hline Cistus salviifolius & $489^{\mathrm{m}}$ & $878^{\text {ij }}$ & $105^{\text {def }}$ & $23.2^{\mathrm{ijk}}$ & $412^{\mathrm{ijkl}}$ & 252 klmno & $150 \mathrm{fg}$ & $24.3^{\mathrm{op}}$ & $620^{b c}$ & $8.66^{b c}$ \\
\hline Calicotome villosa & $227^{\mathrm{t}}$ & 918 efghi & $188^{\mathrm{a}}$ & $28.8 \mathrm{ghi}$ & 529 bc & $429 \mathrm{bc}$ & $104^{\text {hijk }}$ & $3.42 \mathrm{q}$ & 553 de & 7.90 def \\
\hline Erica arborea & $567^{\text {efgh }}$ & $979^{a b}$ & $82.3^{\text {hijkl }}$ & $96.1^{\mathrm{a}}$ & 437 ghi & $337 \mathrm{fg}$ & $244^{c}$ & $114^{\text {efg }}$ & 499 fghi & 6.74 ghij \\
\hline Lavandula stoechas & $293^{s}$ & $947^{\text {abcdef }}$ & $105^{\text {def }}$ & $90.9^{a}$ & $413^{\mathrm{ijkl}}$ & $256^{\text {klmno }}$ & $172^{\mathrm{f}}$ & $2.73 \mathrm{q}$ & $717^{\mathrm{a}}$ & $10.4^{\mathrm{a}}$ \\
\hline Myrtus communis & $556^{\text {fghi }}$ & $956^{\text {abcde }}$ & $92.2^{\text {fghij }}$ & $44.3^{\text {de }}$ & $382 \mathrm{klmn}$ & $229 \mathrm{pqr}$ & 119 hij & $103 \mathrm{ghi}$ & $506^{\mathrm{fgh}}$ & $7.20^{\text {efgh }}$ \\
\hline Pistacia lentiscus & 542 ghij & $956^{\text {abcde }}$ & $96.8^{\text {efghi }}$ & 28.6 ghi & 451 fgh & 293 hij & 124 ghi & $173^{b}$ & 533 ef & 7.42 efg \\
\hline Phillyrea media & $522^{\mathrm{jkl}}$ & $961^{\text {abcde }}$ & $110^{\mathrm{de}}$ & $25.1^{\text {hijk }}$ & $398^{\mathrm{jklm}}$ & $271^{\mathrm{jk} l}$ & $177^{\text {ef }}$ & $3.23^{q}$ & $527^{\text {efg }}$ & $7.46^{\text {efg }}$ \\
\hline Rubus ulmifolius & $363^{r}$ & 925 defgh & $135^{b}$ & $17.7^{\mathrm{jk}}$ & $378^{\operatorname{lmn}}$ & $214 \mathrm{qr}$ & $79.9^{\mathrm{klm}}$ & $144^{\mathrm{c}}$ & 441 lmno & $5.81 \mathrm{klmn}$ \\
\hline SEM & 20.9 & 5.43 & 5.19 & 4.94 & 10.1 & 10.6 & 8.52 & 10.5 & 14.7 & 0.24 \\
\hline \multicolumn{11}{|l|}{ Summer } \\
\hline Arbutus unedo & $662^{a b}$ & $967^{\mathrm{abcd}}$ & $54.8^{\mathrm{op}}$ & $93.6^{\mathrm{a}}$ & $464^{\text {efg }}$ & $328 \mathrm{fg}$ & $246^{c}$ & $133^{\text {cde }}$ & $556^{\text {de }}$ & $7.75^{\text {def }}$ \\
\hline Cistus crispus & 537 hij & $952^{\text {abcdef }}$ & $62.8^{\text {nop }}$ & $24.9^{\text {hijk }}$ & $247 \mathrm{q}$ & $236^{\text {mnopq }}$ & $216^{\mathrm{cd}}$ & $69.5^{\mathrm{klm}}$ & 443 klmno & $5.88^{\mathrm{klmn}}$ \\
\hline Cistus monspeliensis & $691^{\mathrm{a}}$ & 943 bcdefg & 82.8 ghijkl & $90.4^{\mathrm{a}}$ & $493^{\text {cde }}$ & $266^{\mathrm{jklm}}$ & $171^{\mathrm{f}}$ & $64.4^{\mathrm{lm}}$ & 408 op & $5.33 \mathrm{mn}$ \\
\hline Cistus salviifolius & $440^{\circ p}$ & $849^{j}$ & $81.5^{\text {hijklm }}$ & $51.9^{\mathrm{cd}}$ & 502 bcd & 352 ef & $245^{c}$ & $85.8^{\mathrm{ijk}}$ & 443 klmno & $6.03 \mathrm{jklm}$ \\
\hline Calicotome villosa & $496^{\mathrm{ml}}$ & $987^{\text {a }}$ & $190^{\mathrm{a}}$ & $25.8^{\text {hijk }}$ & $616^{\mathrm{a}}$ & $464^{\mathrm{a}}$ & $112^{\text {hij }}$ & $2.47 \mathrm{q}$ & 470 hijkl & $6.29 \mathrm{ijkl}$ \\
\hline Erica arborea & $656^{\mathrm{b}}$ & $969^{a b c}$ & $53.3 \mathrm{P}$ & $91.7^{\mathrm{a}}$ & $536^{\mathrm{b}}$ & $403^{\mathrm{cd}}$ & $373^{\text {a }}$ & $119^{\text {defg }}$ & $360 \mathrm{q}$ & $4.41 \mathrm{P}$ \\
\hline Lavandula stoechas & $476^{\mathrm{mn}}$ & 944 bcdefg & 87.4 ghijk & 36.2 efg & $468^{\text {defg }}$ & $313 \mathrm{gh}$ & $226^{\mathrm{cd}}$ & $3.51 \mathrm{q}$ & 501 fghi & 6.84 ghi \\
\hline Myrtus communis & $535^{\mathrm{ijk}}$ & $946^{\text {abcdef }}$ & $73.4^{\mathrm{klmn}}$ & $39.7^{\text {ef }}$ & $366^{\mathrm{mno}}$ & $233^{\text {nopq }}$ & $95.4^{\mathrm{ijkl}}$ & $129^{\text {cdef }}$ & $566^{\text {de }}$ & $7.93^{\text {cde }}$ \\
\hline Pistacia lentiscus & $619^{c}$ & $948^{\text {abcdef }}$ & $99.5^{\text {defg }}$ & $23.8^{\text {hijk }}$ & $486^{\text {def }}$ & $263^{j \mathrm{klmn}}$ & $178^{\text {ef }}$ & $206^{\mathrm{a}}$ & $454^{\mathrm{jklmn}}$ & $6.53^{\text {hijk }}$ \\
\hline Phillyrea media & $612^{\mathrm{cd}}$ & $966^{\mathrm{abcd}}$ & 85.7 ghijk & 27.0 ghij & 434 ghij & $268^{\mathrm{jklm}}$ & $127^{\mathrm{gh}}$ & $2.57 \mathrm{q}$ & $417^{\text {nop }}$ & $5.80 \mathrm{klmn}$ \\
\hline Rubus ulmifolius & $405 \mathrm{q}$ & $944^{\text {bcdefg }}$ & $115^{\mathrm{cd}}$ & $20.8^{\mathrm{ijk}}$ & $372 \mathrm{mn}$ & $218 \mathrm{pqr}$ & $72.1 \mathrm{~lm}$ & $138^{\mathrm{cd}}$ & $438^{\operatorname{lmno}}$ & $6.38^{\mathrm{ijk}}$ \\
\hline SEM & 16.4 & 6.42 & 6.45 & 5.03 & 16.6 & 13.2 & 14.7 & 11.2 & 10.5 & 0.17 \\
\hline \multicolumn{11}{|l|}{ Autumn } \\
\hline Arbutus unedo & $447^{\text {no }}$ & 952 abcdef & $64.6^{\mathrm{mnop}}$ & $72.1^{b}$ & $495^{\text {cde }}$ & 380 de & $232^{\mathrm{cd}}$ & $124^{\text {cdef }}$ & $395 \mathrm{pq}$ & 5.22 no \\
\hline Cistus crispus & $340^{r}$ & $927^{\text {cdefgh }}$ & 74.7 klmn & $17.4^{\mathrm{jk}}$ & $375^{\mathrm{mn}}$ & 255 klmno & $173^{f}$ & $58.1 \mathrm{mn}$ & $510 \mathrm{fgh}$ & $7.16^{\text {fgh }}$ \\
\hline Cistus monspeliensis & $369^{r}$ & $936^{\text {cdefgh }}$ & $66.7^{1 m n o p}$ & $86.0^{\mathrm{a}}$ & 436 ghi & 307 ghi & $228^{\mathrm{cd}}$ & $79.3^{\mathrm{jkl}}$ & $508^{\mathrm{fgh}}$ & $6.92 \mathrm{ghi}$ \\
\hline Cistus salviifolius & $348^{r}$ & 903 ghi & $67.8^{\text {lmnop }}$ & $39.6^{\text {ef }}$ & 485 def & 293 hij & $230^{\mathrm{cd}}$ & $51.5^{\mathrm{mn}}$ & $464^{\mathrm{ijklm}}$ & $6.34^{\mathrm{ijk}}$ \\
\hline Calicotome villosa & $295^{\mathrm{s}}$ & $955^{\text {abcde }}$ & $197^{\mathrm{a}}$ & $24.8^{\text {hijk }}$ & $594^{\text {a }}$ & $446^{\mathrm{ab}}$ & $126^{\mathrm{gh}}$ & $2.09 \mathrm{q}$ & $359 \mathrm{q}$ & 4.57 op \\
\hline Erica arborea & $506^{\mathrm{klm}}$ & $968^{a b c}$ & $68.0^{\text {lmnop }}$ & 42.9 def & $584^{\text {a }}$ & $459^{a b}$ & $323^{b}$ & $117^{\text {efg }}$ & $426^{\text {mnop }}$ & $5.56^{\mathrm{lmn}}$ \\
\hline Lavandula stoechas & $405 \mathrm{q}$ & $912^{\text {fghi }}$ & $70.5^{\mathrm{klmno}}$ & $33.7 \mathrm{fgh}$ & 436 ghi & 294 hij & $211^{d}$ & $1.93 \mathrm{q}$ & $526^{\text {efg }}$ & 7.40 efg \\
\hline Myrtus communis & $434^{\circ p q}$ & $946^{\text {abcdefg }}$ & $80.5^{\mathrm{ijklm}}$ & $22.5^{\mathrm{ijk}}$ & 334 op & $243^{\text {lmnopq }}$ & $92.1^{\mathrm{jkl}}$ & $111^{\text {fgh }}$ & 492 ghij & $7.33^{\text {efg }}$ \\
\hline Pistacia lentiscus & 591 cde & 952 abcdef & $98.4^{\text {defgh }}$ & $22.5^{\mathrm{ijk}}$ & 419 hijk & $279 \mathrm{ijk}$ & $168^{\mathrm{f}}$ & $195^{\mathrm{a}}$ & 483 hijk & 6.75 ghij \\
\hline Phillyrea media & $575^{\text {ef }}$ & 963 abcd & $78.3^{\mathrm{jklmn}}$ & 28.5 ghi & $425^{\text {hij }}$ & $266^{\mathrm{jklm}}$ & $123^{\text {ghi }}$ & $2.93^{q}$ & 427 mnop & $5.93^{\mathrm{klmn}}$ \\
\hline Rubus ulmifolius & $411 \mathrm{pq}$ & 944 bcdefg & $127^{b c}$ & $19.7^{\mathrm{ijk}}$ & 361 no & $199^{\mathrm{r}}$ & $61.2^{\mathrm{m}}$ & 122 defg & 451 jklmn & $6.47^{\text {hijk }}$ \\
\hline SEM & 16.1 & 3.80 & 6.77 & 3.80 & 14.3 & 14.0 & 12.8 & 10.5 & 9.01 & 0.16 \\
\hline \multicolumn{11}{|l|}{$p$-Value } \\
\hline Season & $<0.001$ & 0.071 & $<0.001$ & $<0.001$ & $<0.001$ & $<0.001$ & $<0.001$ & $<0.001$ & $<0.001$ & $<0.001$ \\
\hline Plant species & $<0.001$ & $<0.001$ & $<0.001$ & $<0.001$ & $<0.001$ & $<0.001$ & $<0.001$ & $<0.001$ & $<0.001$ & $<0.001$ \\
\hline Season $\times$ Plant species & $<0.001$ & $<0.001$ & $<0.001$ & $<0.001$ & $<0.001$ & $<0.001$ & $<0.001$ & $<0.001$ & $<0.001$ & $<0.001$ \\
\hline
\end{tabular}

ADF, acid detergent fiber; ADL, acid detergent lignin; $\mathrm{CP}$, crude protein; $\mathrm{CT}$, condensed tannins; DM, dry matter; EE, ether extract; IVOMD, in vitro organic matter digestibility; ME, metabolizable energy; NDF, neutral detergent fiber; OM, organic matter; SEM, standard error of the mean. Within a column, values with different letters are significantly different $(p<0.05)$

The outcomes for the correlation between chemical components and digestibility with intake and selection are presented in Table 7. The correlation of plants' chemical components with intake rate showed no significant association of EE during all seasons and for fibers during summer and autumn. In spring, fibers and CT were negatively correlated with intake and selection $(p<0.01)$. During all seasons, $\mathrm{CP}$ was positively correlated with intake and selection $(p<0.05)$. 
Table 6. Seasonal variation in the chemical composition (g/kg DM), IVOMD (g/kg), and ME $(\mathrm{MJ} / \mathrm{kg} \mathrm{DM})$ of selected tree species by indigenous Beni Arouss goats grazing a Mediterranean forest rangeland of Northern Morocco.

\begin{tabular}{|c|c|c|c|c|c|c|c|c|c|c|}
\hline & DM & OM & $\mathrm{CP}$ & $\mathrm{EE}$ & NDF & ADF & ADL & $\mathrm{CT}$ & IVOMD & ME \\
\hline \multicolumn{11}{|l|}{ Spring } \\
\hline Olea europaea & $466^{g}$ & $958^{a}$ & $78.7^{\text {cde }}$ & $97.4^{\mathrm{b}}$ & $419 \mathrm{~g}$ & $317^{\mathrm{d}}$ & $161^{\mathrm{cd}}$ & $4.20^{\mathrm{f}}$ & $511^{c}$ & 7.04 ef \\
\hline Quercus coccifera & $567^{\mathrm{f}}$ & $957^{\mathrm{a}}$ & $105^{\mathrm{a}}$ & $18.3^{\mathrm{e}}$ & $489^{f}$ & $343^{\mathrm{cd}}$ & $132^{\mathrm{f}}$ & $18.4^{\mathrm{e}}$ & $613^{a}$ & $8.93^{a}$ \\
\hline Quercus ilex & $576^{\mathrm{f}}$ & $952^{a}$ & $109^{a}$ & $18.7^{\mathrm{e}}$ & $548^{b c}$ & $349^{c}$ & $191^{\mathrm{a}}$ & $29.3^{c}$ & $515^{c}$ & $7.33^{\mathrm{de}}$ \\
\hline Quercus suber & 584 ef & $970^{a}$ & $88.4^{b c}$ & 23.4 de & $589^{\text {a }}$ & $386^{\mathrm{ab}}$ & $174^{\mathrm{abc}}$ & $119^{b}$ & $549^{b}$ & $8.13^{b}$ \\
\hline SEM & 14.5 & 4.42 & 3.91 & 10.1 & 19.6 & 7.64 & 6.64 & 13.5 & 12.6 & 0.227 \\
\hline \multicolumn{11}{|l|}{ Summer } \\
\hline Olea europaea & $436^{h}$ & $914^{\mathrm{b}}$ & $91.6^{b}$ & $121^{a}$ & $444^{\mathrm{g}}$ & $255^{f}$ & 150 de & $2.57^{\mathrm{f}}$ & $525^{b c}$ & $8.08^{b}$ \\
\hline Quercus coccifera & $693^{a}$ & $963^{a}$ & $66.6^{\mathrm{e}}$ & $25.4^{\mathrm{d}}$ & $552^{b}$ & $389 \mathrm{ab}$ & $172 \mathrm{bc}$ & $21.4^{\text {de }}$ & 429 ef & $5.74^{\mathrm{h}}$ \\
\hline Quercus ilex & $611^{\mathrm{cd}}$ & $951^{a}$ & $71.2^{\text {de }}$ & $19.3^{\mathrm{e}}$ & $532^{\mathrm{bcd}}$ & $353^{c}$ & $182^{a b}$ & $61.2^{c}$ & $421^{\mathrm{f}}$ & $5.83^{h}$ \\
\hline Quercus suber & $648^{\mathrm{b}}$ & $959^{a}$ & $79.0^{\text {cde }}$ & $27.0^{\mathrm{d}}$ & 502 ef & $363^{b c}$ & 144 ef & $138^{a}$ & 460 de & $6.43^{\mathrm{g}}$ \\
\hline SEM & 29.4 & 5.97 & 2.93 & 2.93 & 12.5 & 15.6 & 4.98 & 15.6 & 12.6 & 0.285 \\
\hline \multicolumn{11}{|l|}{ Autumn } \\
\hline Olea europaea & $422^{h}$ & $916^{b}$ & $81.1^{\mathrm{bcd}}$ & $77.2^{\mathrm{c}}$ & $443 \mathrm{~g}$ & $286^{e}$ & $179^{a b c}$ & $2.77^{\mathrm{f}}$ & $521^{b c}$ & $7.81^{b c}$ \\
\hline Quercus coccifera & 629 bc & $967^{a}$ & $71.0^{\text {de }}$ & 23.0 de & 522 cde & $401^{\mathrm{a}}$ & $175^{a b c}$ & $16.8^{\mathrm{e}}$ & $463^{d}$ & $6.50 \mathrm{~g}$ \\
\hline Quercus ilex & 600 de & $963^{a}$ & $70.8^{\text {de }}$ & $18.8^{\mathrm{e}}$ & 503 def & $347^{c}$ & $170^{\mathrm{bc}}$ & $54.6^{c}$ & $477^{\mathrm{d}}$ & $6.73^{\mathrm{fg}}$ \\
\hline Quercus suber & 602 de & $957^{\mathrm{a}}$ & $89.4^{b c}$ & $25.9^{d}$ & $488^{f}$ & $317^{\mathrm{d}}$ & $134^{\text {ef }}$ & $125^{b}$ & $525^{\mathrm{bc}}$ & $7.58^{\mathrm{cd}}$ \\
\hline SEM & 24.9 & 6.49 & 2.58 & 7.21 & 8.78 & 13.0 & 5.63 & 14.3 & 8.40 & 0.168 \\
\hline \multicolumn{11}{|l|}{$p$-Value } \\
\hline Season & $<0.001$ & 0.023 & $<0.001$ & $<0.001$ & $<0.001$ & 0.016 & 0.507 & $<0.001$ & $<0.001$ & $<0.001$ \\
\hline Plant species & $<0.001$ & $<0.001$ & 0.144 & $<0.001$ & $<0.001$ & $<0.001$ & $<0.001$ & $<0.001$ & $<0.001$ & $<0.001$ \\
\hline Season $\times$ Plant species & $<0.001$ & 0.001 & $<0.001$ & $<0.001$ & $<0.001$ & $<0.001$ & $<0.001$ & $<0.001$ & $<0.001$ & $<0.001$ \\
\hline
\end{tabular}

$\mathrm{ADF}$, acid detergent fiber; $\mathrm{ADL}$, acid detergent lignin; $\mathrm{CP}$, crude protein; $\mathrm{CT}$, condensed tannins; $\mathrm{DM}$, dry matter; $\mathrm{EE}$, ether extract; IVOMD, in vitro organic matter digestibility; ME, metabolizable energy; NDF, neutral detergent fiber; OM, organic matter; SEM, standard error of the mean. Within a column, values with different letters are significantly different $(p<0.05)$.

Table 7. Correlation coefficient between chemical component variables and digestibility with intake and selection.

\begin{tabular}{|c|c|c|c|c|c|c|c|c|c|}
\hline & & EE & NDF & ADF & ADL & $\mathrm{CP}$ & $\mathrm{CT}$ & IVDMD & IVOMD \\
\hline Intake rate & $\begin{array}{l}\text { Spring } \\
\text { Summer } \\
\text { Autumn }\end{array}$ & $\begin{array}{l}0.029 \\
0.036 \\
-0.06\end{array}$ & $\begin{array}{c}-0.42 * * * \\
0.04 \\
-0.03\end{array}$ & $\begin{array}{c}-0.39 * * * \\
0.02 \\
0.09\end{array}$ & $\begin{array}{c}-0.10 * * \\
-0.02 \\
0.06\end{array}$ & $\begin{array}{l}0.11^{* *} \\
0.21^{* *} \\
0.08^{*}\end{array}$ & $\begin{array}{c}-0.38^{* * *} \\
0.58^{* * *} \\
0.63^{* * *}\end{array}$ & $\begin{array}{l}0.52^{* * *} \\
0.09^{* *} \\
0.08^{* *}\end{array}$ & $\begin{array}{c}0.57^{* * *} \\
0.07^{*} \\
0.11\end{array}$ \\
\hline Selection & $\begin{array}{l}\text { Spring } \\
\text { Summer } \\
\text { Autumn }\end{array}$ & $\begin{array}{c}0.09^{* *} \\
-0.22^{* * *} \\
-0.24^{* * *}\end{array}$ & $\begin{array}{c}-0.25^{* * *} \\
0.11^{* * *} \\
-0.120^{* * *}\end{array}$ & $\begin{array}{c}-0.27^{* * *} \\
-0.01 \\
-0.11^{* * *}\end{array}$ & $\begin{array}{l}-0.15^{* *} \\
-0.45^{* * *} \\
-0.36^{* * *}\end{array}$ & $\begin{array}{c}0.19^{* *} \\
0.26^{* * *} \\
0.07^{*}\end{array}$ & $\begin{array}{c}-0.36^{* * *} \\
0.10^{* * *} \\
0.13^{* * *}\end{array}$ & $\begin{array}{c}0.51^{* * *} \\
0.07^{*} \\
0.17^{* * *}\end{array}$ & $\begin{array}{c}0.53^{* * * *} \\
-0.03 \\
0.09^{* *}\end{array}$ \\
\hline
\end{tabular}

EE, ether extract; NDF, neutral detergent fiber; $\mathrm{ADF}$, acid detergent fiber; ADL, lignin; $\mathrm{CP}$, crude protein; $\mathrm{CT}$, condensed tannins; IVDMD, in vitro dry matter digestibility; IVOMD, in vitro organic matter digestibility. Significance level $\left({ }^{* * *}<0.001,{ }^{* *}<0.01\right.$, and $\left.{ }^{*}<0.05\right)$.

\section{Discussion}

\subsection{Forage Availability and Diet Selection}

The study revealed that shrubs, mainly A. unedo, Cistus spp., and E. arborea, formed the most available and prevalent forage species in the study area, which is in accordance with several authors $[19,25]$, who studied the botanical composition of forest rangeland in Northern Morocco. The forage availability depended considerably on the season and the existing plant species. The low forage availability recorded in the summer and autumn could be due to the vegetation cycle and to the weather conditions more favorable to the growth of plants during spring. In the Mediterranean forests of Northern Morocco, Chebli et al. [19] also confirmed the strong seasonality of forage availability even for woody species that are usually less impacted by seasonal fluctuations.

According to Papachristou et al. [40], the bulk of the small ruminants' diet includes a limited number of woody and herbaceous species, usually less than ten species. Some species despite their abundance in the pasture were negatively selected, and conversely. Similar results were announced by Baraza et al. [41] in the Mediterranean mountain forest of Spain and by Ventura-Cordero et al. [13] in a tropical deciduous forest of México. As reported by some studies $[9,17]$, woody species were more selected by goats independently to the season. Despite the low availability of tree species (Quercus spp. and O. europaea) 
and some shrubs (M. communis, P. lentiscus, P. media, and R. ulmifolius) they were selected preferentially in summer and autumn. It could be supposed that goats select a wide range of mixed plant species in order to meet their foraging requirements. Likewise, VenturaCordero et al. [13] reported that diet selection was not necessarily correlated with the forage availability, but it appears more linked to satisfying the feed needs of goats. During spring, the great selectivity for herbaceous could be associated with their higher availability and quality. In Eastern and Northern Mediterranean rangelands, Papachristou [42] and Glasser et al. [11] also stated the higher selection of herbaceous during spring due to their high nutritive value and availability compared to the other seasons. According to Ferreira et al. [43], goats increase their preference for herbaceous species in spring due to their easy access, better flavor, and high digestibility. As described by Dziba et al. [44], the high elasticity of goats' diet could be explained by their great ability to switch from one vegetation strata to another. Generally, goats have been considered as opportunistic grazers in forest pasture and marginal land $[45,46]$.

\subsection{Feeding Behaviour}

The seasonality of feeding behaviour was confirmed by several studies conducted in the Monte desert of Argentina [47], South African woodland [48], and Greek woodland [14]. The results showed that woody species represented more than $90 \%$ of DC and TB in all seasons. The same trend of the feeding behaviour of goats was reported by Manousidis et al. [17]. Cistus spp. and L. stoechas were more grazed during spring compared to summer and autumn due to the presence of fresh leaves and new long-shoots. Aharon et al. [9] reported that goats spent more time browsing Cistus spp. during spring compared to other seasons despite the abundance of herbaceous species. On the opposite, Papachristou [42] reported that goats in Greek forest rangeland ingested mainly Cistus spp. during autumn. The high ingestion of trees, mainly Quercus spp., was observed during summer and autumn. This increase could be explained by intake reduction of some plants such as Cistus spp. species and herbaceous species. Similar findings were reported by Manousidis et al. [17] concerning the high contribution of Quercus spp. to the diet of goats' in a similar Mediterranean woodland area. As expected, when herbaceous species were less abundant and dry, goats trended to more graze woody species [49]. In agreement with Barros et al. [23], goats recorded faster BR in the summer and autumn in order to maximize their IR. Papachristou [42] also signaled an increase of BR from spring to summer which is in accordance with our outcomes. Despite the high availability of $A$. unedo and E. arborea, they were avoided during all seasons. C. villosa, Quercus spp., M. communis, and P. lentiscus were highly consumed by goats mainly in the fall and summer regardless of their low availability. Cistus spp. and L. stoechas were selected proportionally to their abundance only during the spring.

\subsection{Forage Quality: Chemical Composition, Digestibility and Metabolizable Energy}

Chemical analyses of the hand-plucked samples appear to reflect the nutritive value of the diet consumed by grazing goats [16].

The analyses showed a wide variability of pasture quality, which is in accordance with previous grazing studies conducted in tropical deciduous forest [21], South African rangeland [48] and Mediterranean woodland [16]. The seasonal changes of feed quality could be explained by the chemical and physiological plant variations during the different growth stages [50]. The CP was higher during spring for all species because plants contain the maximum CP content during the vegetative stage [51]. The decrease of this parameter in the summer agrees with the literature $[52,53]$ because it drops with physiological maturity stage of the plant [54]. The range of $60-70 \mathrm{~g} / \mathrm{kg}$ DM of CP is the limit threshold for an efficient feed utilization; a lower CP content negatively affects feed intake and digestibility [55]. In the present work, all species but A. unedo and E. arborea during summer had higher $\mathrm{CP}$ values than this threshold. As reported by Dziba et al. [44], it could be assumed that due to its palatability and high content on CP, C. villosa was highly consumed in summer 
and autumn despite the presence of spines known for their negative effect on BR and IR. According to Min et al. [56], the CT concentration of $20-45 \mathrm{~g} / \mathrm{kg}$ DM has a negative effect on protein digestibility and proteolytic bacteria, and more than $55 \mathrm{~g} / \mathrm{kg}$ DM reduces the voluntary feed intake of grazing ruminants $[57,58]$. Thus, except for herbaceous, C. villosa, L. stoechas, P. media, and O. europaea, all pastoral species had CT content higher than this maximum level. However, even with a high content of $C T$, the shrubs group were highly consumed in spring and autumn. These finding are consistent with Fomum et al. [48] and Mkhize et al. [59], who reported no correlation between CT and feed intake of goats. The lack of CT effect on forage intake and selectivity could be explained by the ability of goat to balance their diet and dilute secondary compounds by consuming a mixture of plant species [60,61]. Further, animals exposed to a tannin-rich environment have the capacity to produce proline-rich proteins capable of irreversibly binding the CT [57,59]. Nevertheless, goats have a specificity compared to other ruminants that their ruminal microbiota is able to valorize feed with low nutritional values due to their cellulolytic bacteria and the tanninase activity [62]. The high values of digestibility in spring are attributed to its positive dependence on proteins and negative correlation with ADF and ADL [16]. In the summer, OM digestibility declines because of fibers increase [63] and cell wall lignification [64] which are considered as limiting factors for plant digestibility [65]. Most of the pastoral species had a low digestibility and consequently a low energy content (IVOMD $<550 \mathrm{~g} / \mathrm{kg}$; $\mathrm{ME}<8 \mathrm{MJ} / \mathrm{kg} \mathrm{DM}$ ) except for herbaceous and some shrubs (A. unedo and Cistus spp.), which their values varied from medium (550-700 g/ $\mathrm{kg}$ IVOMD; ME: 8-10 MJ $/ \mathrm{kg}$ DM) to higher nutritional values (IVOMD > $700 \mathrm{~g} / \mathrm{kg}$; ME > 10) especially in spring [66]. As reported by Paton [63], ME depends mainly on IVOMD. The positive correlation between CP with intake and selection is consistent with Mkhize et al. funding [59]. Conversely, Fomum et al. [48] observed no correlation between intake and CP in both the dry and rainy seasons. During spring, condensed tannins affect negatively intake [67]. There was no significant correlation between condensed tannins and intake during dry and rainy seasons [48]. Overall, goats select species with high $\mathrm{CP}$ and digestibility, and low fibers contents basis in accord with the literature [40]. Goats selected successively shrubs, herbaceous, and trees in spring and shrubs, trees, and herbaceous in autumn. Their preference was based on the high content of $\mathrm{CP}$ and the availability of the selected plant groups. Emmans [68] reported that animal selects among available plant species, those with nutritional values nearest to its dietetic requirements. Barroso et al. [28] added that the diet of goats is rather related to many variables hardly measurable than just nutritional value. According to the literature, diet of goats depended mainly on their nutritional requirements, physical traits such as shoot morphology and leaf phenology [59], environmental circumstances [24], and on the specific flavor of each consumed species [69].

\section{Conclusions}

The results emphasized the importance of the Southern Mediterranean silvopastoral areas for indigenous goats. The dietary quality of ingested forage and feeding behaviour of goats are currently known. Most studied parameters vary across seasons. Woody species are the most selected species by the indigenous goats. Their intake did not necessarily depend on the forage availability and nutritional value of plant species; it could be rather related to ensuring they meet their feeding needs as best as possible. Overall, these findings could be used as the first guide for future studies and managers interested in feeding behaviour of grazing goats in the Mediterranean forest rangeland of northern Morocco. The goats' ability to select tanniferous woody forage and a wide range of plant species could probably promote the floristic biodiversity of forest rangeland, only under rational use condition of forage resources.

Author Contributions: Conceptualization, Y.C.; methodology, Y.C., M.C., J.-L.H., J.B., J.-F.C.; formal analysis, Y.C., S.E.O.; investigation, Y.C., S.E.O., A.K.; data curation, Y.C., M.C., J.-L.H., J.-F.C.; writing-original draft preparation, Y.C., S.E.O., M.C., J.-L.H., A.K., J.B., J.-F.C.; project administration, 
Y.C., J.-F.C.; funding acquisition, Y.C. All authors have read and agreed to the published version of the manuscript.

Funding: This research was funded by the Academy for Research and Higher Education-Development Cooperation Committee (ARES-CCD), Brussels, Belgium. This study is realized in the framework of the Research Project for Development (PRD: 2013-2018).

Institutional Review Board Statement: Not applicable.

Informed Consent Statement: Not applicable.

Data Availability Statement: The data presented in this study are available from the corresponding author on request.

Acknowledgments: The authors wish to acknowledge PRD Project and INRA staffs. We thank the herders for their patience and participation in this study.

Conflicts of Interest: The authors declare no conflict of interest.

\section{References}

1. Chebli, Y.; El Otmani, S.; Elame, F.; Moula, N.; Chentouf, M.; Hornick, J.-L.; Cabaraux, J.-F. Silvopastoral System in Morocco: Focus on Their Importance, Strategic Functions, and Recent Changes in the Mediterranean Side. Sustainability 2021, $13,10744$. [CrossRef]

2. Chentouf, M.; Boulanouar, B.; Bister, J.L. Elevage Caprin au Nord du Maroc; INRA-Editions Press: Rabat, Morocco, 2015; 168p.

3. El Otmani, S.; Chebli, Y.; Taminiau, B.; Chentouf, M.; Hornick, J.-L.; Cabaraux, J.-F. Effect of Olive Cake and Cactus Cladodes Incorporation in Goat Kids' Diet on the Rumen Microbial Community Profile and Meat Fatty Acid Composition. Biology 2021, 10, 1237. [CrossRef] [PubMed]

4. Hilal, B.; Boujenane, I.; El Otmani, S.; Chentouf, M.; Piro, M. Genetic characterization of hamra goat population in two different locations of Morocco using microsatellite markers. Iran. J. Appl. Anim. Sci. 2016, 6, 901-907.

5. El Otmani, S.; Chebli, Y.; Chentouf, M.; Hornick, J.L.; Caba-raux, J.F. Effects of Olive Cake and Cactus Cladodes as Alternative Feed Resources on Goat Milk Production and Quality. Agriculture 2021, 11, 3. [CrossRef]

6. El Otmani, S.; Chebli, Y.; Hornick, J.L.; Cabaraux, J.F.; Chentouf, M. Growth performance, carcass characteristics and meat quality of male goat kids supplemented by alternative feed resources: Olive cake and cactus cladodes. Anim. Feed. Sci. Technol. 2021, 272, 114746. [CrossRef]

7. Silanikove, N. The physiological basis of adaptation in goats to harsh environments. Small Rumin. Res. 2000, 35, 181-193. [CrossRef]

8. Kababya, D.; Perevolotsky, A.; Bruckental, I.; Landau, S. Selection of diets by dual-purpose Mamber goats in Mediterranean woodland. J. Agric. Sci. 1998, 131, 221-228. [CrossRef]

9. Aharon, H.; Henkin, Z.; Ungar, E.; Kababya, D.; Baram, H.; Perevolotsky, A. Foraging behaviour of the newly introduced Boer goat breed in a Mediterranean woodland: A research observation. Small Rumin. Res. 2007, 69, 144-153. [CrossRef]

10. Papachristou, T.; Dziba, L.; Villalba, J.J.; Provenza, F.D. Patterns of diet mixing by sheep offered foods varying in nutrients and plant secondary compounds. Appl. Anim. Behav. Sci. 2007, 108, 68-80. [CrossRef]

11. Glasser, T.; Landau, S.; Ungar, E.; Perevolotsky, A.; Dvash, L.; Muklada, H.; Kababya, D.; Walker, J. Foraging selectivity of three goat breeds in a Mediterranean shrubland. Small Rumin. Res. 2012, 102, 7-12. [CrossRef]

12. Koluman, N.; Boga, M.; Silanikove, N.; Gorgulu, M. Performance and eating behaviour of crossbred goats in Mediterranean climate of Turkey. Rev. Bras. Zootec. 2016, 45, 768-772. [CrossRef]

13. Ventura-Cordero, J.; González-Pech, P.; Sandoval-Castro, C.A.; Torres-Acosta, J.F.J.; Tun-Garrido, J. Feed resource selection by Criollo goats browsing a tropical deciduous forest. Anim. Prod. Sci. 2017, 58, 2314-2320. [CrossRef]

14. Manousidis, T.; Parissi, Z.; Kyriazopoulos, A.; Malesios, C.; Koutroubas, S.; Abas, Z. Relationships among nutritive value of selected forages, diet composition and milk quality in goats grazing in a Mediterranean woody rangeland. Livest. Sci. 2018, 218, 8-19. [CrossRef]

15. Chebli, Y.; Chentouf, M.; Ozer, P.; Hornick, J.-L.; Cabaraux, J.-F. Forest and silvopastoral cover changes and its drivers in northern Morocco. Appl. Geogr. 2018, 101, 23-35. [CrossRef]

16. Chebli, Y.; El Otmani, S.; Chentouf, M.; Hornick, J.-L.; Cabaraux, J.-F. Temporal Variations in Chemical Composition, In Vitro Digestibility, and Metabolizable Energy of Plant Species Browsed by Goats in Southern Mediterranean Forest Rangeland. Animals 2021, 11, 1441. [CrossRef]

17. Manousidis, T.; Kyriazopoulos, A.; Parissi, Z.; Abraham, E.; Korakis, G.; Abas, Z. Grazing behavior, forage selection and diet composition of goats in a Mediterranean woody rangeland. Small Rumin. Res. 2016, 145, 142-153. [CrossRef]

18. Agreil, C.; Meuret, M. An improved method for quantifying intake rate and ingestive behaviour of ruminants in diverse and variable habitats using direct observation. Small Rumin. Res. 2004, 54, 99-113. [CrossRef]

19. Chebli, Y.; El Otmani, S.; Chentouf, M.; Hornick, J.-L.; Bindelle, J.; Cabaraux, J.-F.; Chebli, Y. Foraging Behavior of Goats Browsing in Southern Mediterranean Forest Rangeland. Animals. 2020, 10, 196. [CrossRef] [PubMed] 
20. Meuret, M.; Provenza, F.D. How French shepherds create meal sequences to stimulate intake and optimise use of forage diversity on rangeland. Anim. Prod. Sci. 2015, 55, 309-318. [CrossRef]

21. González-Pech, P.G.; Torres-Acosta, J.F.D.J.; Sandoval-Castro, C.A.; Tun-Garrido, J.; de Jesús Torres-Acosta, J.F.; Sand-oval-Castro, C.A.; Tun-Garrido, J. Feeding behavior of sheep and goats in a deciduous tropical forest during the dry season: The same menu consumed differently. Small Rumin. Res. 2015, 133, 128-134. [CrossRef]

22. Cook, C.W. Symposium on Nutrition of Forages and Pastures: Collecting Forage Samples Representative of Ingested Material of Grazing Animals for Nutritional Studies. J. Anim. Sci. 1964, 23, 265-270. [CrossRef]

23. Barros, C.S.; Dittrich, J.R.; Rocha, C. Comportamento de caprinos em pasto de Brachiaria hibrida cv. mulato. Rev. Fac. Veterinária Zootec. Agron. 2007, 14, 187-206.

24. Pontes, L.D.S.; Agreil, C.; Magda, D.; Gleizes, B.; Fritz, H. Feeding behaviour of sheep on shrubs in response to contrasting herbaceous cover in rangelands dominated by Cytisus scoparius L. Appl. Anim. Behav. Sci. 2010, 124, 35-44. [CrossRef]

25. Chebli, Y.; Chentouf, M.; Hornick, J.L.; Cabaraux, J.F. Extensive goat production systems in northern Morocco: Production and use of pastoral resources. In Grassland Resources for Extensive Farming Systems in Marginal Lands: Major Drivers and Future scenarios; Porqueddu, A., Franca, C., Lombardi, A., Molle, G., Peratoner, G., Hopkins, G., Eds.; Wageningen Academic Publishers Press: Wageningen, The Netherlands, 2017; pp. 131-133.

26. Lechowicz, M. The sampling characteristics of electivity indices. Oecologia 1982, 52, 22-30. [CrossRef]

27. Ivlev, V.S. Experimental Ecology of the Feeding of Fishes; Yale University Press: New Haven, CT, USA, 1961; 302p.

28. Barroso, F.G.; Alados, C.L.; Boza, J. Food selection by domestic goats in Mediterranean arid shrublands. J. Arid Environ. 1995, 31, 205-217. [CrossRef]

29. Makkar, H.P.S.; Singh, B. Effect of drying conditions on tannin, fibre and lignin levels in mature oak (Quercus incana) leaves. $J$. Sci. Food Agric. 1991, 54, 323-328. [CrossRef]

30. AOAC. Official Methods of Analysis, 16th ed.; Association of Analytical Chemists: Arlington, VA, USA, 1997.

31. Mertens, D.R. Gravimetric determination of amylase-treated neutral detergent fiber in feeds with refluxing in beakers or crucibles: Collaborative study. J. AOAC Int. 2002, 85, 1217-1240.

32. AOAC. Official Methods of Analysis, 15th ed.; Association of Analytical Chemists: Arlington, VA, USA, 1990.

33. Robertson, J.B.; Van Soest, P.J. The Detergent System of Analysis; James, W.P.T., Theander, O., Eds.; The Analysis of dietary Fibre in Food; Marcel Dekker: New York, NY, USA, 1981; pp. 123-158.

34. Porter, L.J.; Hrstich, L.N.; Chan, B.G. The conversion of procyanidins and prodelphinidins to cyanidin and delphinidin. Phytochemistry 1986, 25, 223-230. [CrossRef]

35. Mabjeesh, S.; Cohen, M.; Arieli, A. In Vitro Methods for Measuring the Dry Matter Digestibility of Ruminant Feedstuffs: Comparison of Methods and Inoculum Source. J. Dairy Sci. 2000, 83, 2289-2294. [CrossRef]

36. Tassone, S.; Fortina, R.; Peiretti, P.G. In Vitro Techniques Using the Daisy II Incubator for the Assessment of Digestibility: A Review. Animals. 2020, 10, 775. [CrossRef]

37. El Otmani, S.; Chentouf, M.; Hornick, J.L.; Cabaraux, J.F. Chemical composition and in vitro digestibility of alternative feed resources for ruminants in Mediterranean climates: Olive cake and cactus cladodes. J. Agric. Sci. 2019, 157, 260-271. [CrossRef]

38. Steel, R.G.D.; Torrie, J.H. Principles and Procedures of Statistics, 2nd ed.; McGraw-Hill: New York, NY, USA, 1980.

39. Littell, R.C.; Henry, P.R.; Ammerman, C.B. Statistical analysis of repeated measures data using SAS procedures. J. Anim. Sci. 1998, 76, 1216-1231. [CrossRef]

40. Papachristou, T.; Platis, P.; Nastis, A. Foraging behaviour of cattle and goats in oak forest stands of varying coppicing age in Northern Greece. Small Rumin. Res. 2005, 59, 181-189. [CrossRef]

41. Baraza, E.; Hódar, J.A.; Zamora, R. Consequences of plant-chemical diversity for domestic goat food preference in Mediterranean forests. Acta Oecol. 2009, 35, 117-127. [CrossRef]

42. Papachristou, T. Foraging behaviour of goats and sheep on Mediterranean kermes oak shrublands. Small Rumin. Res. 1997, 24, 85-93. [CrossRef]

43. Ferreira, L.M.M.; Celaya, R.; Benavides, R.; Jáuregui, B.M.; García, U.; Santos, A.S.; García, R.R.; Rodrigues, M.A.M.; Osoro, K. Foraging behaviour of domestic herbivore species grazing on heathlands associated with improved pasture areas. Livest. Sci. 2013, 155, 373-383. [CrossRef]

44. Dziba, L.; Scogings, P.; Gordon, I.; Raats, J. Effects of season and breed on browse species intake rates and diet selection by goats in the False Thornveld of the Eastern Cape, South Africa. Small Rumin. Res. 2003, 47, 17-30. [CrossRef]

45. Harris, S.E. Cyprus as a degraded landscape or resilient environment in the wake of colonial intrusion. Proc. Natl. Acad. Sci. USA 2012, 109, 3670-3675. [CrossRef]

46. Lovreglio, R.; Sahar, O.; Leone, V. Goat grazing as a wildfire prevention tool: A basic review. IForest-Biogeosci. For. 2014, 7, 260-268. [CrossRef]

47. Egea, A.; Allegretti, L.; Lama, S.P.; Grilli, D.; Sartor, C.; Fucili, M.; Guevara, J.; Passera, C. Selective behavior of Creole goats in response to the functional heterogeneity of native forage species in the central Monte desert, Argentina. Small Rumin. Res. 2014, 120, 90-99. [CrossRef]

48. Fomum, S.W.; Scogings, P.F.; Dziba, L.; Nsahlai, I.V. Seasonal variations in diet selection of Nguni goats: Effects of physical and chemical traits of browse. Afr. J. Range Forage Sci. 2015, 32, 193-201. [CrossRef] 
49. Sanon, H.; Kaboré-Zoungrana, C.; Ledin, I. Behaviour of goats, sheep and cattle and their selection of browse species on natural pasture in a Sahelian area. Small Rumin. Res. 2007, 67, 64-74. [CrossRef]

50. Egea, A.; Allegretti, L.; Lama, S.P.; Grilli, D.; Fucili, M.; Guevara, J.; Villalba, J. Diet mixing and condensed tannins help explain foraging preferences by Creole goats facing the physical and chemical diversity of native woody plants in the central Monte desert (Argentina). Anim. Feed. Sci. Technol. 2016, 215, 47-57. [CrossRef]

51. Mero, R.N.; Udén, P. Promising tropical grasses and legumes as feed resources in central Tanzania. VI. Nitrogen balance in growing bulls consuming tropical herbaceous forage legumes. Anim. Feed. Sci. Technol. 1998, 72, 387-396. [CrossRef]

52. Hassen, A.; Rethman, N.; Van Niekerk, W.; Tjelele, T. Influence of season/year and species on chemical composition and in vitro digestibility of five Indigofera accessions. Anim. Feed. Sci. Technol. 2007, 136, 312-322. [CrossRef]

53. Safari, J.; Mushi, D.; Kifaro, G.; Mtenga, L.; Eik, L. Seasonal variation in chemical composition of native forages, grazing behaviour and some blood metabolites of Small East African goats in a semi-arid area of Tanzania. Anim. Feed. Sci. Technol. 2011, 164, 62-70. [CrossRef]

54. Rawnsley, R.; Donaghy, D.J.; Fulkerson, W.J.; Lane, P.A. Changes in the physiology and feed quality of cocksfoot (Dactylis glomerata L.) during regrowth. Grass Forage Sci. 2002, 57, 203-211. [CrossRef]

55. Minson, D.J. Forage in Ruminant Nutrition; Academic Press: New York, NY, USA, 1990.

56. Min, B.; Barry, T.; Attwood, G.; McNabb, W. The effect of condensed tannins on the nutrition and health of ruminants fed fresh temperate forages: A review. Anim. Feed Sci. Technol. 2003, 106, 3-19. [CrossRef]

57. Waghorn, G. Beneficial and detrimental effects of dietary condensed tannins for sustainable sheep and goat production-Progress and challenges. Anim. Feed Sci. Technol. 2008, 147, 116-139. [CrossRef]

58. Dove, H. Ingestive behaviour, diet selection, and feed intake. In Goat Science and Production; Solaiman, S.G., Ed.; Wiley-Blackwell: Ames, IA, USA, 2010; pp. 179-192.

59. Mkhize, N.R.; Scogings, P.F.; Nsahlai, I.V.; Dziba, L. Diet selection of goats depends on season: Roles of plant physical and chemical traits. Afr. J. Range Forage Sci. 2014, 31, 209-214. [CrossRef]

60. Iason, G.R.; Villalba, J.J. Behavioral Strategies of Mammal Herbivores Against Plant Secondary Metabolites: The AvoidanceTolerance Continuum. J. Chem. Ecol. 2006, 32, 1115-1132. [CrossRef]

61. Rogosic, J.; Pfister, J.; Provenza, F.; Grbesa, D. Sheep and goat preference for and nutritional value of Mediterranean maquis shrubs. Small Rumin. Res. 2006, 64, 169-179. [CrossRef]

62. Molina-Alcaide, E.; Yáñez-Ruiz, D. Potential use of olive by-products in ruminant feeding: A review. Anim. Feed Sci. Technol. 2008, 147, 247-264. [CrossRef]

63. Paton, D. Elaboration of a multi-variate model for the determination of the metabolizable energy of Mediterranean bushes based on chemical parameters. J. Arid Environ. 2003, 53, 271-280. [CrossRef]

64. Kozloski, G.; Perottoni, J.; Sanchez, L. Influence of regrowth age on the nutritive value of dwarf elephant grass hay (Pennisetum purpureum Schum. cv. Mott) consumed by lambs. Anim. Feed. Sci. Technol. 2005, 119, 1-11. [CrossRef]

65. Van Soest, P.J. Nutritional Ecology of the Ruminant, 2nd ed.; Cornell University Press: Ithaca, NY, USA, 1994; p. 476. [CrossRef]

66. Tainton, N. Veld Management in South Africa; University of Natal Press: Pietermaritzburg, South Africa, $1999 ;$ p. 472.

67. Papachristou, T.G.; Nastis, A.S.; Mathur, R.; Hutchings, M.R. Effect of physical and chemical plant defences on herbivory: Implications for Mediterranean shrubland management. Basic Appl. Ecol. 2003, 4, 395-403. [CrossRef]

68. Emmans, G.C. Diet selection by animals: Theory and experimental design. Proc. Nutr. Soc. 1991, 50, 59-64. [CrossRef]

69. De Rosa, G.; Moio, L.; Napolitano, F.; Grasso, F.; Gubitosi, L.; Bordi, A. Influence of Flavor on Goat Feeding Preferences. J. Chem. Ecol. 2002, 28, 269-281. [CrossRef] [PubMed] 